\title{
Joint impacts of immigration on wages and employment: review and meta-analysis
}

\author{
S. Longhi • P. Nijkamp · J. Poot
}

Received: 24 June 2009/Accepted: 25 February 2010/Published online: 31 March 2010

(C) The Author(s) 2010. This article is published with open access at Springerlink.com

\begin{abstract}
A burgeoning literature has emerged during the last two decades to assess the economic impacts of immigration on host countries. In this paper, we outline the quantitative approaches presented in the literature to estimate the impact of immigration on the labour market, particularly at the regional level. We then revisit the joint impacts of immigration on wages and employment using a metaanalytic approach. As a novel contribution to previous meta-analyses on labour market impacts, we use a simultaneous equations approach to the meta-analysis of wage and employment effects. Using 129 effect sizes, we find that the observed local wage and employment effects are very small indeed. Generally, the employment impact is more pronounced in Europe than in the United States. Controls for endogeneity show a somewhat more negative impact. Wage rigidity increases the magnitude of the employment impact on the native born. The demarcation of the local labour market in terms of geography and skills matters also.
\end{abstract}

Keywords International migration - Regional labour market · Meta-analysis · Migration impact assessment

JEL Classification $\quad \mathrm{F} 22 \cdot \mathrm{J} 61 \cdot \mathrm{R} 23$

\footnotetext{
S. Longhi

Institute for Social and Economic Research, University of Essex, Colchester, UK

P. Nijkamp

Department of Spatial Economics, VU University, Amsterdam, The Netherlands

J. Poot $(\bowtie)$

Population Studies Centre, University of Waikato, Hamilton, New Zealand

e-mail: jpoot@waikato.ac.nz
} 


\section{Migration impact assessment: prefatory remarks}

Migration is not a recent phenomenon but has occurred throughout the history of mankind. In our modern open world, international migration has become a prominent response to complex space-time dynamics in open socio-economic systems. Most countries are increasingly affected by international migration: either as senders of emigrants, as receivers of immigrants, or in many cases as both. The composition of the migrant population is often very different from that of the host population in terms of demographic, cultural and socio-economic characteristics. Migrant settlement is worldwide also predominantly concentrated in specific attraction regions and in metropolitan agglomerations.

The demographic and socio-economic impacts of international migration have become in recent decades a source of concern to policy-makers and the public at large, as well as a source of inspiration for scientific research (see Bommes and Morawska 2005; Macura et al. 2005). An avalanche of studies has been published on the causes, consequences, absorption capacity, social tension and regulatory regimes associated with the large-scale international mobility of people. All this research has been triggered by the tremendous growth in permanent and temporary migration. The number of foreign-born residents in countries worldwide almost doubled to 200 million in the period 1985-2005 (GCIM 2005). Many developed countries have seen the percentage of the resident population that is born overseas increase to double digits. Although the global economic downturn triggered by the 2008 financial crisis lowered cross-border mobility temporarily — because labour mobility is generally pro-cyclical (OECD 2009) — further integration of the world's labour markets is likely in the long-run.

It is noteworthy that most studies on international migration focus on the average impact at the national level, while impact assessments for specific regions or cities are rather rare. ${ }^{1}$ The predominantly national focus is intriguing as most problems-but also opportunities - associated with international migration are experienced at local or regional levels. Migrants are not evenly distributed within countries but adopt a self-selected spatial choice behaviour that leads to geographical clusters. In some countries, policies are in place that encourage dispersion (such as higher admission points being given to visa applicants who are willing to settle in peripheral regions), but such policies may not be effective due to the freedom of subsequent internal relocation. Emigrants are often spatially clustered as well. This holds for all classes of migrants: migrants from former colonies, business migrants, labour migrants, lifestyle migrants (such as retired persons), international students and refugees.

Furthermore, migrants are characterised by a high degree of heterogeneity with respect to skills, education, age, gender, welfare position, cultural background, and motivation. It is therefore no wonder that we do not only observe spatially diverse patterns of migrant departure and settlement, but also large differences in socioeconomic impacts of foreign migrants. For example, in the large metropolitan

\footnotetext{
${ }^{1}$ Gorter et al. (1998) provide an overview of regional and urban perspectives. More recently, Nathan (2008) considered local impacts in the UK. Partridge et al. (2008) and Chappell et al. (2009) focussed on outcomes in rural America and rural UK, respectively.
} 
areas immigration reinforces agglomeration dynamics. In contrast, rural areas may only attract seasonal foreign workers to be employed in the primary sector, while many provincial towns may only be affected by immigration indirectly (through internal migration and general equilibrium effects). This 'new geography of immigration' offers ample evidence that it is not possible to give an unambiguous and general answer to the question whether international migration is beneficial or not for host and/or sending regions. Nevertheless, many important and specific research questions can be asked regarding the local impact of international migration.

The focus of the present paper is on the labour market impact of immigration, particularly at the regional level. We first outline the various quantitative methodologies that have been presented in the literature to estimate the labour market impact of immigration. We then address an important knowledge issue in this context, viz. the joint impact on wages and employment of foreign migrants in the host local labour market. In simple terms, it can be said that because an immigration shock affects both the supply and demand sides of labour and output markets - through a variety of mechanisms in the short-run and in the long-run- the combined effect is an empirical matter. Even a model that ties down the supply side of the local economy by means of the neoclassical theory of factor demand, and thereby unambiguously predicts a decline in wages in the short-run following positive immigration, cannot theoretically predict the impact in the long-run unless consumption effects are known (Borjas 2009).

In the next section, we review the applied quantitative studies that have been used to empirically measure wage and employment impacts. In Sect. 3, we then briefly summarise some previously conducted meta-analyses that synthesise the international empirical evidence regarding labour market impacts of immigration. Several meta-analyses have been undertaken where the international empirical evidence on either the 'price' or the 'quantity' aspect of the labour market impact was summarised. We explicitly consider the difference between national effects and effects on local labour markets.

Naturally, the wage and employment impacts of an immigration shock are not unrelated: they depend inter alia on the wage elasticities of the demand for and the supply of labour. In the present paper, we adopt a novel approach of deploying a simultaneous equations meta-regression model for assessing wage and employment impacts jointly. The number of existing primary studies that can be combined in such a simultaneous equations regression model is to date rather limited, but we found seven comparable primary studies that yielded 129 useful meta-observations. These are analysed in Sect. 4. We find small wage and employment impacts, even smaller than have been detected in previous metaanalytic research. A $1 \%$ point increase in the share of immigrants in a local labour market of the typical host country decreases wages of the native born by $0.029 \%$ (using a weighted average with weights determined by the precision of the estimates) and decreases employment of the native born by $0.011 \%$. The employment outcome among the native born suggests a positive wage elasticity of local 
labour supply of $0.379 .^{2}$ This is the combined local labour market effect of a decline in labour force participation and outward migration following a positive immigration shock.

The very small wage and employment impacts are perhaps not surprising as the present focus is on the localised effects which tend to be smaller than the national effects. However, we find that the definition of the local labour market in terms of geography and skills matters. Moreover, the employment impact is more pronounced in Europe than in the United States. Finally, controls for endogeneity of the immigration shock show a somewhat more negative employment impact.

One source of positive economic spillover effects of immigration on the host population that may offset potentially negative wage and employment effects is an endogenous production technology in which total factor productivity growth is positively associated with immigration. Again, these effects are often localised. The extent to which immigration induces creativity, innovation and technological change is an emerging topic in the immigration literature that is briefly considered in Sect. 5. Section 6 provides a short summary and suggestions for further research.

The focus in the present paper is solely on migrant receiving areas. The impact on labour markets in source countries and regions is also attracting renewed attention and the classic perspective of emigrants being positively self-selected in terms of skills and unmeasured ability-the so-called brain drain (see, e.g., Bhagwati 1976) — has been challenged in recent years (see, e.g., Commander et al. 2003; Mayr and Peri 2008). It is argued that the higher returns obtainable abroad to investments in education and training encourage a greater proportion of the work force to invest in human capital than otherwise, thereby generating a positive spillover in the source labour market. Furthermore, the incidence of return migration and circulation is increasing, and the return of diaspora raises human capital levels and entrepreneurship in the source country and region. The discussion of such migrant source country perspectives is beyond the scope of the present paper (for a recent review, see Duncan 2008).

\section{Quantitative methodologies to assess economic impacts of immigration}

Immigrants affect both the supply side and the demand of the local economy from the day of arrival. On the supply side, one or more members of the migrant household are likely to enter the local labour market, which directly affects the supply of labour with skills and attributes similar to those of the immigrants. The impact on other workers, either native born or earlier immigrants, depends greatly on the extent to which the different types of labour can substitute for each other in production and the extent to which firms change the composition of output and production methods following an immigration-induced labour supply shock. On the demand side, migrant earnings and/or migrant wealth, and sometimes social security

\footnotetext{
${ }^{2}$ Let $E$ and $M$ refer to employment of natives and immigrants, respectively. Then $\Delta \ln E / \Delta$ $[M /(M+E)]=\Delta \ln E / \Delta \ln w \times \Delta \ln w / \Delta[M /(M+E)]$. Hence, if $\Delta \ln E / \Delta[M /(M+E)]=-0.011$ and $\Delta \ln w / \Delta$ $[M /(M+E)]=-0.029$, then $\Delta \ln E / \Delta \ln w=0.379$ (the wage elasticity of local labour supply).
} 
payments, fund the consumption and housing of migrant households. Public expenditure on key items such as education and health will also be affected, although less so when such sectors operate below full capacity utilisation before a positive migration shock. As on the supply side, the specifics of the demand shock will depend on characteristics of the migrants and of the location. In the longer run, migration shocks lead to changes in the level and composition of investment by firms. Technologies and future migration patterns, internally and internationally, may also be affected. Consequently, long-run impacts may be quite different from those in the short-run. Figure 1 shows the simple textbook case of homogenous labour in which a supply shock in a specific region $r$ due to immigration shifts the supply curve there from $S_{\mathrm{r}}$ to $S_{\mathrm{r}}^{\prime}$. The increase in the scale of the local population due to immigration raises the demand for locally produced goods and services (e.g., Mazzolari and Neumark 2009). To the extent that these are not traded externally and prices are therefore set locally, the increase in demand increases output prices and volume. The demand curve for labour moves to $D_{\mathrm{r}}^{\prime}$. At this point, however, wages are $w^{*}$, i.e., lower than in the rest of the nation $\mathrm{RN}$, and some adjustment may be expected due to capital and labour mobility. Figure 1 shows the case of labour flowing from $r$ to RN (shifting supply in $r$ to $S_{\mathrm{r}}^{\prime \prime}$ and in $\mathrm{RN}$ to $S_{\mathrm{RN}}{ }^{\prime}$ ) with spatial equilibrium being restored at wage level $w^{* *}$.

The impact of immigration on employment and wages is jointly determined by the wage elasticities of supply and demand, and the various ways in which demand and supply schedules change, either in a general equilibrium or in a disequilibrium framework. With respect to the factors that determine the magnitude of the local and national labour market impacts, we need to distinguish between local determinants and national determinants. At both levels, a distinction must be made between shortrun and long-run processes. Table 1 tabulates the various determinants and the time frames over which they may impact on the labour market outcomes.

The limited space does not permit a detailed review of all the determinants listed in Table 1. It is clear that, besides the wage elasticities of labour supply and demand at the local level, many factors play a role in determining the local labour market

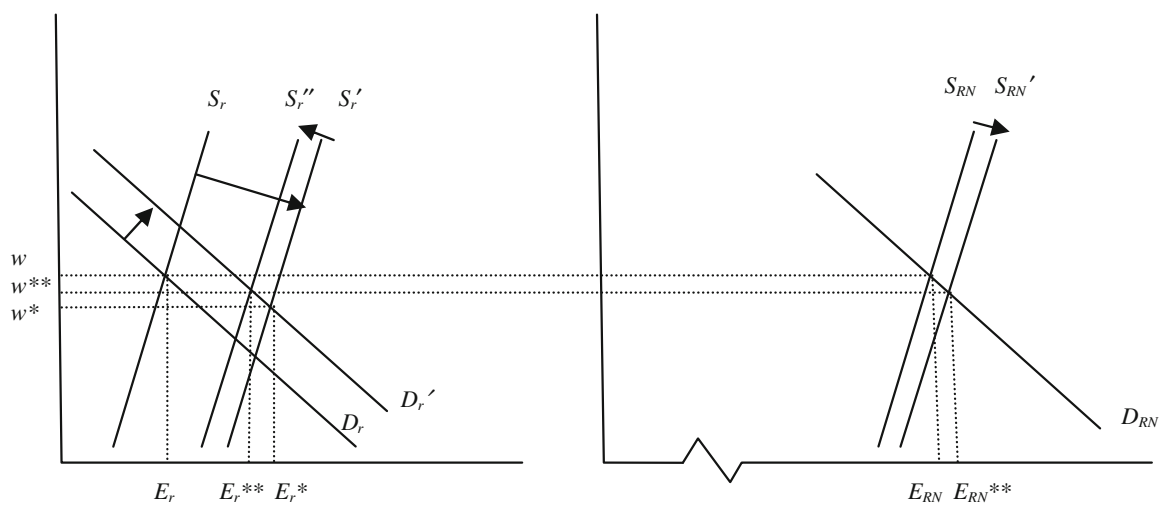

Fig. 1 Local and national wage and employment impacts of a positive immigration shock in a specific local labour market 
Table 1 Factors that determine the magnitude of the local and national wage and employment impacts of a positive immigration shock in a local labour market

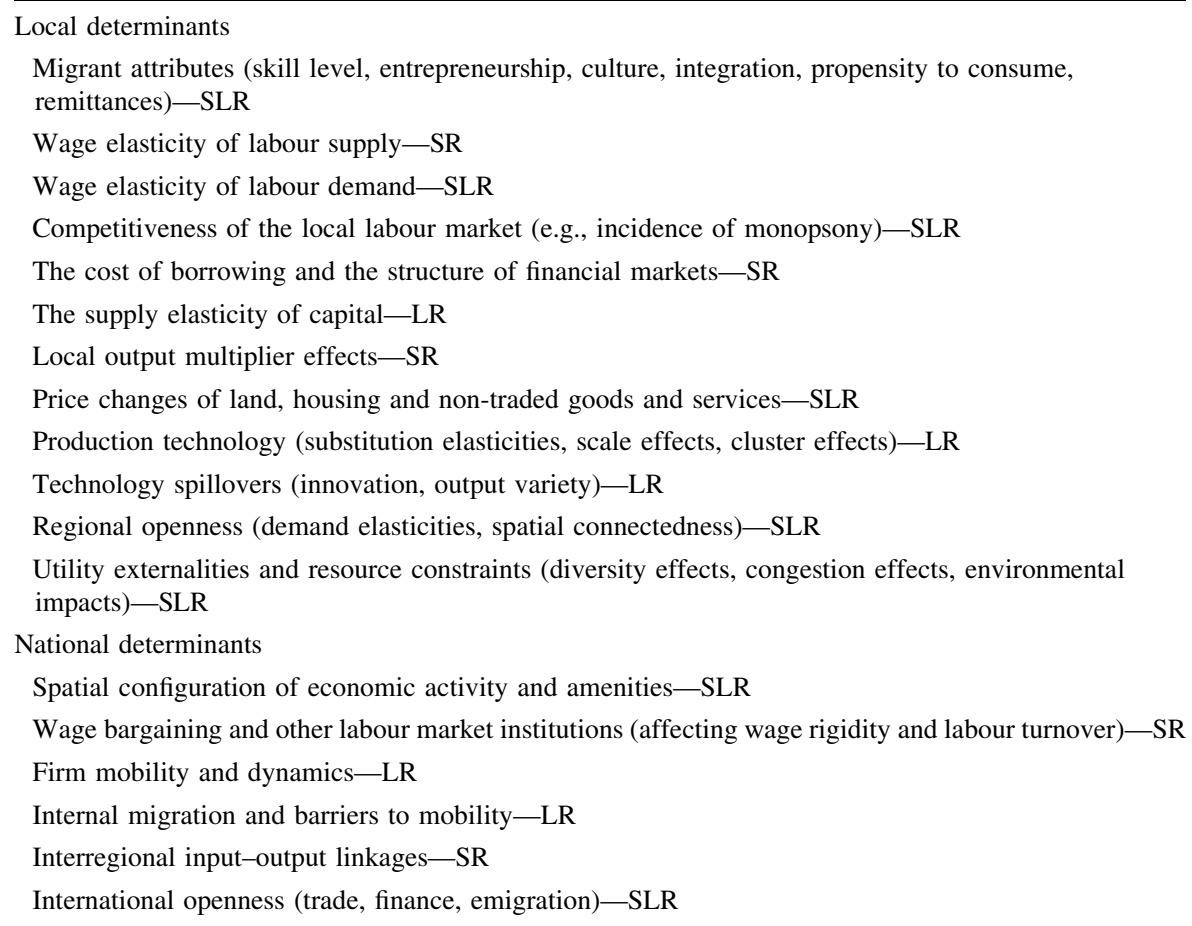

SR - operates predominantly short-run, LR — operates predominantly long-run, SLR —operates in both short-run and long-run

outcomes following a labour supply shock through immigration. These would include some factors that have been well studied, such as the attributes of the migrants themselves; or the effect on local prices of land, housing and non-traded goods (see Saiz 2007; Lach 2007; Cortes 2008). The role of some other determinants is less well known, such as the competitiveness of the local labour market, multiplier effects and spatial connectedness; as well as various long-run factors such as capital accumulation, technological spillovers and environmental effects. National determinants would include labour market institutions, the extent of internal migration and firm mobility, but also the openness of the nation in international terms (such as the extent to which immigration triggers an emigration response). Many of these determinants warrant further investigation.

Many methodologies have been proposed to capture these labour market and broader impacts. Extensive reviews are beyond the scope of this paper, but see e.g., Dustmann et al. (2008); Hanson (2008); Pekkala Kerr and Kerr (2008); Okkerse (2008); and Poot and Cochrane (2005). Basically, a distinction can be made between simulation methods and econometric estimation. We will consider these in turn. 


\subsection{Simulation methods}

With simulation methods, a theoretical model is formulated and the parameters are borrowed from other studies or calibrated on available data. The simplest example is the calculation of the so-called migrant surplus following an immigrant-generated labour supply increase under the assumption of perfect substitutability between migrants and natives (see Borjas 1999). Similarly, Borjas (2009) shows that with homogenous labour in a one-good Cobb-Douglas economy, the short-run wage elasticity of a supply shock due to immigration would be equal to minus the share of capital in income, e.g., -0.3 in the US.

A somewhat more disaggregated method considers the relative contribution of immigrants to the skilled and unskilled labour supply in a country and assumes perfect substitutability between the native born and migrants within each skill group. For a given constant elasticity of substitution between skill types (estimated, or borrowed from other studies), the change in the skill premium following an immigration shock can then be calculated (e.g., Borjas et al. 1992). This is referred to as the factor proportions approach.

A limitation of this partial equilibrium/factor proportions approach is that it does not take into account the economy-wide repercussions following a labour supply shock. Computable general equilibrium (CGE) models take instead an economywide disaggregated approach that offers in principle the greatest potential for capturing the many and varied impacts of an immigration shock. A recent example is Nana et al. (2009) who calculate the economy-wide impacts of a wide range of immigration scenarios for New Zealand. Similarly, Baas and Brücker (2010) calculate the impact of East-West migration into Germany and the United Kingdom; Barret et al. (2005) simulate the impact of immigration into Ireland, while Sarris and Zografakis (1999) analyse the impact of illegal immigration on the Greek economy.

While CGE models have also been constructed for regional level analysis, such applications are still relatively rare although they offer great potential (Partridge and Rickman 2008; Donaghy 2009). A rare example of applying this type of model to simulation of regional impacts of immigration is Park and Hewings (2009) who explore the impact of changing immigration levels in Chicago with a two-region CGE model (Chicago and Rest of the United States), integrated with an Overlapping Generations model. CGE models have huge data requirements that are less likely to be met at the regional level. Assuming that at the regional level, price effects are small and of secondary concern, a favourite tool for local impact assessment-the regional input-output model (which is also at the core of a CGE model) — can be used instead. An example is Gans (2007) who calculates the economic impacts of immigrants in the state of Arizona. More attention should also be paid to the resulting internal migration flows, for example using network autocorrelation approaches such as proposed by Chun (2008).

A final simulation approach that deserves mention is that of microsimulation. An example is given by Rephann and Holm (2004), who develop a dynamic spatial microsimulation model of immigration in Sweden. As with the national CGE 
models, this study finds that the experienced levels of immigration have had only very modest impacts on the economy and the labour market.

\subsection{Econometric estimation}

\subsubsection{The production function approach}

The first empirical estimates of the impact of immigration on the labour market of the host country date back to Grossman (1982). In her theoretical framework, native and immigrant workers are considered as separate inputs in a translog production function. The effect of a supply shock-due to an influx of immigrants-is simulated given the specified production technology. The elasticities of substitution between groups of native and immigrant workers-leading to corresponding effects of immigration on natives' wages - are then computed using US data for 1970. Thus, Grossman conducts a factor proportion approach in which the production function parameters are econometrically estimated before the impact on wages of a labour supply shock are calculated. A similar approach has been used to estimate the impact of immigration for a number of other countries and periods by, among others, Borjas (1987); Greenwood et al. (1997); and Peri (2007) for the US; Bauer (1998) for Germany; and Akbari and Devoretz (1992) for Canada.

The general conclusion from these studies is that the impact of immigration on the native born is economically small, and often not statistically significant. It can be argued that results from the factor proportions approach, simulated or econometrically estimated, are rather sensitive to the adopted theoretical assumptions and modelling choices and specifically to the choice of the production function (e.g., Greenwood et al. 1996 on this point).

\subsubsection{Natural experiments}

Card (1990) estimates the impact of immigration at a local level by analysing a specific exogenous shock referred to in the literature as a natural experiment (Meyer 1995). He exploits the sudden increase in Miami's labour supply given by the 1980 influx of Cuban immigrants (the so-called Mariel boat lift). By using a differencein-differences estimator, Card (1990) concludes that this large immigration shock, which increased Miami's labour force by $7 \%$ almost overnight, had no significant impact on Miami's native labour market outcomes. Several mechanisms have been proposed to explain this outcome. For example, Lewis (2004) suggests that the small impact on labour market opportunities of low-skill natives might be due to Miami employers taking advantage of the large pool of cheap unskilled labour by using labour-intensive production technologies rather than adopting the laboursaving technological changes (such as information technology investments) that occurred elsewhere.

Natural experiments are often considered as the best way to isolate the impact of an exogenous shock. Nevertheless, even when very good instruments are available, the impact of immigration on the labour market opportunities of natives might not be correctly estimated. This is likely to be due to various processes that are not 
taken into account in the analysis, such as immigrant expenditures that increase local demand; outward migration of natives; or reallocation of resources. Also, as noted earlier, a distinction should be made-but is often ignored in empirical analyses-between short-run and long-run impacts (e.g., Greenwood et al. 1996; Gross 2004; Poot and Cochrane 2005; Borjas 2009). The long-run impact may be not only of a different magnitude but even of a different sign from the short-run impact.

There are also other studies that estimate the labour market impact of immigration by exploiting an exogenous variation in labour supply, such as the return of repatriates from Africa to Portugal (Carrington and de Lima 1996); the return of repatriates from Algeria to France (Hunt 1992); the immigration of Russian Jews into Israel (Friedberg 2001; Cohen-Goldner and Paserman 2006); the influx of immigrants into Western Europe from the former Yugoslavia (Angrist and Kugler 2003); and the influx of immigrants from Central America to the US following hurricane Mitch (Kugler and Yuksel 2008). In contrast to Card (1990), these studies exploiting well-defined exogenous shocks do not use a difference-indifferences estimator; rather, they estimate the impact of immigration on the labour market by exploiting the spatial variation of immigration across local labour markets of the receiving country, in an 'area approach' setting, to which we will now turn.

\subsubsection{Area approach}

The most common method to estimate the impact of immigration on the labour market is the so-called area or spatial correlation approach, pioneered by King et al. (1986). The area approach estimates the impact of immigration on the local labour market by exploiting the fact that immigrants tend to concentrate within the receiving country in few local labour markets. ${ }^{3}$ This spatial selectivity is so strong that, as noted earlier, the best determinant of the subnational distribution of the flow of new immigrants may well be the spatial distribution of the stock of the foreignborn population (Card 2009; van der Gaag and van Wissen 2001). However, this does not imply that no new patterns can emerge in the spatial distribution of new arrivals. Changes in the spatially differentiated demand for labour and in the composition of immigration flows can affect the spatial settlement patterns. For example, recent migrants from Central and Eastern Europe have disproportionally moved to rural areas in the United Kingdom in response to labour shortages in key sectors such as agriculture, food processing and hospitality (Chappell et al. 2009).

If immigrants have a negative impact on wages of natives, we would expect a negative spatial correlation between the proportion of immigrants in a local labour market and the wages of natives for whom they can substitute. The impact of immigration is typically estimated using a regression equation with on the left-hand side the labour market variable of interest (e.g., wages, employment, unemployment,

\footnotetext{
3 Although these studies exploit the spatial correlation between the share of immigrants and the labour market variable of interest, they generally estimate only an average nation-wide impact of immigration. The possibility of spatial heterogeneity of the impact is usually ignored in this context as this cannot be measured without adequate space-time data.
} 
labour force participation), and on the right-hand side the stock or the share of immigrants in the population as the explanatory variable of interest, jointly with other co-variates that may explain labour market outcomes.

Although King et al. (1986) found no impact of Hispanic immigrants on Hispanic American workers, a large number of other studies have used the same approach to estimate the impact of immigration for a large number of other countries and periods. Among others: Bean et al. (1988); Borjas et al. (1996, 1997); Card (2001); Borjas (2003); Aydemir and Borjas (2007) for the US; Pope and Withers (1993); Addison and Worswick (2002) for Australia; Maré and Stillman (2009) for New Zealand; Akbari and Devoretz (1992); Aydemir and Borjas (2007) for Canada; De New and Zimmermann (1994); Pischke and Velling (1997); Winter-Ebmer and Zweimuller (1999); Gavosto et al. (1999); Venturini and Villosio (2006); Gross (2002); Dustmann et al. (2005); Zorlu and Hartog (2005); and Carrasco et al. (2008) for European countries (specifically Austria, Germany, Italy, France, Great Britain, Norway, The Netherlands and Spain).

Although the area approach relies on spatial correlations, it may still treat each area as a single point. If the local labour market is segmented in terms of the spatial, sectoral or occupational distribution of employment, with immigrants being clustered into certain areas, industries or occupations within cities, the observed average impact may be driven by composition effects. In inter-area regression modelling, the intra-area allocation of labour is usually ignored. ${ }^{4}$

\subsubsection{A comparison of production function, natural experiment and area approaches}

Among the three estimation approaches, we might expect that the natural experiment approach would yield the largest estimated impact of immigration. Assuming that an exogenous shock to the labour supply in a local labour market can be clearly identified in a natural experiment, the usual attenuation bias of the measured impact-due to endogeneity of immigration (immigrants go to areas where wage and/or employment growth is the highest) — can be avoided. The fact that even in natural experiments, the measured impact tends to be quite small is indicative of the many and complex secondary order effects (such as accelerated investment, sectoral changes and outward migration of residents) that are triggered by the immigration shock.

Early narrative literature reviews suggest that studies applying the factor proportions/production function approach tended to find larger labour market impacts of immigration than those applying the area approach (e.g., Borjas et al. 1996; Friedberg and Hunt 1995). This is what one would expect given that the former have stronger grounding in the theory of labour demand, whereas the latter tend to be data driven. However, this was surprisingly not borne out by metaanalysis of the-predominantly post 1995-literature that suggested somewhat less negative wage effects in the factor proportions studies than in the area approach studies (Longhi et al. 2005b).

\footnotetext{
${ }^{4}$ We are grateful to one of the referees for pointing this out.
} 
Generally speaking, there are three crucial issues in estimating the relative wage effects of immigration. The first is the extent to which different skill categories in the labour markets are substitutes for each other. The second is the extent to which immigrants and the native born within a specific skill group are substitutes for each other. The third issue is the extent to which physical capital adjusts in the short-run and in the long-run. If immigrants and the native born are only imperfect substitutes within education-experience group and if capital accumulation responds to the greater returns resulting from the expansion of employment, the short-run decline in natives' wages following an immigration shock becomes very small indeed (and many groups of native workers find their wages increase due to complementarity with the immigrants groups), while in the long run the impact on natives tends to be positive. Where negative impacts are found, they only tend to be quantitatively important for earlier immigrants of the same skills and for locally born who are close substitutes to such new arrivals. Using US national level data, Ottaviano and Peri (2008) provide a detailed empirical verification of these broad statements, although the extent to which immigrants and natives within narrowly defined groups in the labour market are imperfect substitutes, remains debated (e.g., Borjas et al. 2008).

It is important to disentangle the contributions of the various assumptions and data sources used to explain the observed distribution of estimates of labour market impacts. Meta-analysis provides a set of techniques that enable us to quantify the sources of differences between study findings (e.g., Cooper and Hedges 1994). Because the native born would be concerned about the combined effect of changes in wages and employment opportunities following an immigration shock, we take in Sect. 4 a simultaneous equations approach to meta-regression analysis of wage and employment elasticities. However, we first provide in the next section a summary of previous meta-analyses of the impact of immigration on different aspects of the labour market, with an emphasis on studies using the area approach.

\section{Previous meta-analyses of the impact of immigration}

\subsection{The research design}

The vast majority of studies estimating the impact of immigration on the labour market of the host country estimate a multivariate regression model in which the labour market variable of interest in the $j$ th local labour market at time $t\left(y_{j t}\right)$ is modelled as a function of, among other variables, a measure of immigration $\left(m_{j t}\right)$ :

$$
y_{j t}=\beta m_{j t}+x_{j t}^{\prime} \alpha+\varepsilon_{j t}
$$

where $y_{j t}$ is either the level or the change of the labour market variable of interest (e.g., wages, employment, unemployment of the native born or of earlier immigrants), with $j$ referring to a geographical area or a population sub-group in a geographical area. The measure of immigration is often the stock of immigrants or the share of immigrants in that particular labour market or a change in one of these two variables 
(i.e., immigration flows), while $\boldsymbol{x}_{j t}$ is a vector of observations on covariates which might vary widely between studies. Because a number of studies adopted the same technique, it has been possible to summarise the results of those studies-which are representative of much of the previous literature-in three meta-analyses of the impact of immigration. These inform on either the distribution of estimates of the parameter $\beta$ or on the statistical significance of these estimates. ${ }^{5}$

In Longhi et al. (2005b), we focus on the impact of immigration on wages and compare 348 estimates collected from 18 papers. The unconditional average elasticity was -0.1 : a $1 \%$ point increase in the share of immigrants in the population would lower wages of the native-born population by about $0.1 \%{ }^{6}$ When migrants are about one tenth of the population, this translates into an elasticity of $-0.01 \%$ for the percentage change in the average wage of the native born, following a $1 \%$ increase in the number of migrants. Alternatively, this implies (assuming migrants and natives are perfect substitutes) a rather elastic labour demand curve: a $1 \%$ decline in wages would increase employment by $10 \%$.

Longhi et al. (2005a) average estimates of the impact of immigration on employment of natives. The comparison of 165 estimates collected from nine studies yielded an unconditional average elasticity of -0.02 (i.e., a $1 \%$ increase in the number of immigrants lowers employment of natives by $0.02 \%$ ). Hence, while both are small, the employment effect appears on average to be somewhat greater than the wage effect. This is not implausible given the extent of wage rigidities in many countries. However, if both elasticities would apply to the same flexible labour market in which equilibrium is quickly restored following a supply shock, these numbers would suggest that the supply of native-born local labour is relatively wage elastic (with an elasticity of two) either through a decline in labour force participation or through outward migration or both. ${ }^{7}$ It should be recalled, however, that the meta-analytical estimates of the wage and employment elasticities are obtained from a range of studies among which only some provide estimates of both impacts. In the present paper, using a set of studies which all yield wage and employment elasticities simultaneously, we find that the employment effect is

\footnotetext{
5 Note that estimates of $\beta$, obtained by regressions of the type specified in Eq. (1), measure an effect that is assumed to be time and space invariant. Moreover, in estimating Eq. (1) authors have in the past ignored the fact that the data are essentially in the form of a spatial panel in which there may be spatial autocorrelation that may bias estimates obtained with non-spatial methods. Econometric estimation techniques such as those suggested by Fischer and Getis (2010), Anselin et al. (2008) and Elhorst (2003) do not appear to have been applied yet in the literature reviewed in this paper. Even in cross-sectional regressions, the estimation of spatial lags or errors in estimation of Eq. (1) is rare. Bryant and Rukumnuaykit (2007) provide estimates of a spatial lag version of the wage impact equation for Thailand.

6 This may be compared to a simple average of a wide range of elasticities reported in Table 7 of a recent survey by Pekkala Kerr and Kerr (2008). The average of their selection of estimates is -0.18 , i.e. a little larger than Longhi et al. (2005b), but still a similarly small magnitude.

7 Recall from footnote 2 that $\Delta \ln E / \Delta[M /(M+E)]=\Delta \ln E / \Delta \ln w \times \Delta \ln w / \Delta[M /(M+E)]$. Hence if $\Delta \ln E / \Delta$ $[M /(M+E)]=-0.02$ and $\Delta \ln w / \Delta[M /(M+E)]=-0.01, \Delta \ln E / \Delta \ln w=2$ (the wage elasticity of local labour supply). The simple average of the employment elasticities reported in Table 8 by Pekkala Kerr and Kerr (2008) is -0.08 (excluding one outlier). Given the earlier reported wage elasticity of -0.18 by them, this implies a labour supply elasticity of +0.44 , which is similar to what is found in the present meta-analysis (see Sect. 4).
} 
smaller than the wage effect, yielding more plausible labour supply elasticities. This is elaborated in the next section.

It can be argued that the 18 and nine studies used in the meta-analysis of wage and employment effects, respectively, are not representative of all studies conducted on the topic of the labour market impact of immigration. Rather than considering the magnitude of the impact of immigration, Longhi et al. (2008) focus just on the sign and statistical significance of the estimated impacts. This choice allowed the comparison of the results of a much larger number of studies (45 in this case), considering different aspects of the labour market. In particular, we compared 1,572 so-called effect sizes in the form of $t$ statistics: 854 on the impact of immigration on wages; 500 on employment; 185 on unemployment; and 33 on labour force participation.

In contrast to early narrative literature reviews (Borjas et al. 1996; Friedberg and Hunt 1995), but consistent with Longhi et al. (2005b), we found that effect sizes estimated using either natural experiments or the econometric factor proportion approaches were less likely to indicate a statistically significant negative impact of immigration. More generally, about half of the 1,572 effect sizes were not statistically significant.

The finding that the estimated impact of immigration is often neither statistically significant nor economically (quantitatively) significant is often attributed to underestimation of the "true" impact. We summarise in the following text some sources of underestimation that are commonly put forward in the literature. Since most of these relate to particular study characteristics that were included in the previous meta-analyses, we also summarise in the following text which of these explanations are supported by the empirical evidence.

\subsection{The effect of the definition of local labour market}

Different definitions of the local labour market are likely to generate different estimated impacts of immigration (Longhi et al. 2005a, b, 2008). Ideally, the local labour market should be defined in a rather narrow way, to better identify workers who might be close substitutes to each other. Following this idea, a number of studies define local labour markets by a combination of geography and occupations or skills (e.g., Borjas et al. 1997; Card 2001); this should lead to the estimation of larger negative native wage and employment impacts of immigration. This may be expected because inter-occupational mobility is less than inter-regional mobility.

Primary studies also differ in their geographical definition of the labour market. Some studies define the local labour market by using small geographical areas such as metropolitan areas in the US or NUTS three regions in the EU (e.g., Borjas et al. 1996; Card 2001; Pischke and Velling 1997; Zorlu and Hartog 2005); others define the local labour market by rather large areas, such as US States or regions, or European countries (e.g., Borjas et al. 1996; Borjas 2003; Friedberg 2001; Angrist and Kugler 2003). Geographically small areas can be considered as small open economies, which are likely to be more affected by spatial interaction and spillovers than larger regions or countries, particularly in the long-run. Adjustment processes in an open labour market such as native out-migration, changes in sectoral and trade 
composition, and capital inflow might bias the estimation of the effect of immigration towards zero in the long-run (Borjas et al. 1997; Card 2001). Hence, we might expect studies focusing on small geographic areas to be more likely to miss a negative effect of immigration. Borjas (2006), for example, finds that the impact of immigration on wages is much higher when estimated at the national level and that the migration of native born accounts for 40-60\% of the difference between the estimates at state level and the estimates at the level of metropolitan areas.

On the other hand, the short-run effects of migration are likely to be markedly local: immigrants are likely to have initially a sizable impact only in the labour market area where they choose to locate. The fact that such local impact is small even in the short-run is likely due to the supply shock coinciding with an immediate increase in local consumption expenditure associated with the enlarged population (Mazzolari and Neumark 2009) and with multiplier effects.

Consistent with Borjas (2006), we found in our previous meta-analyses that elasticities that are computed using geographically narrower definitions of the labour market tend to find much smaller impacts of immigration in magnitude (Longhi et al. 2005a, b). Similarly, when focussing only on sign and statistical significance, we found that statistically significant negative $t$ statistics are relatively less frequent in those studies that use small geographical areas, which can be considered more 'open' than countries to various adjustment mechanisms such as trade, internal migration and capital mobility (Longhi et al. 2008).

Somewhat related to the issue of openness of the labour market, we found that the impact of immigration on wages and employment is larger in magnitude when estimated for European countries rather than for the US, although in terms of statistical significance of the results no difference could be detected. A plausible explanation is that European local labour markets are less open and flexible than those in the US labour market.

\subsection{The effect of region-specific characteristics and the spatial distribution of immigrants}

It is widely recognised that region-specific unobserved characteristics might influence immigrant density and/or natives' outcomes, thus possibly generating biased estimation of the impact of immigration when this is computed on crosssection data (e.g., Altonji and Card 1991; Friedberg and Hunt 1995). Altonji and Card (1991) suggest first-differencing the data in order to correctly capture the short-run effects of immigration. Empirically, however, since most studies use census data, first differences are typically computed over a rather long period of 5-10 years, thus implicitly assuming that these regional-specific characteristics remain constant over a rather long time period. Rather surprisingly, the metaanalysis of the $t$ statistics suggested that primary studies using cross-sectional data were more likely to find a statistically significant negative effect (Longhi et al. 2008). In terms of magnitude, studies using first-differenced rather than crosssectional data found a larger negative impact of immigration, as expected by Altonji and Card (1991); however, this difference was not statistically significant in the meta-regression models (Longhi et al. 2005a, b). 
As noted earlier, another source of possible bias in estimating the impact of immigration on wages is the non-random distribution of immigrants across the labour market areas. If immigrants are attracted to regions where wages are high due to an increase in the local demand for labour, the endogeneity of immigration creates an identification problem, which necessitates the use of instrumental variable estimators (e.g., Friedberg and Hunt 1995; Borjas 1999; Card 2001). In most cases, the instrument chosen is the "migrant stock" at some time in the past under the assumption that immigrants' locational choice might depend more on historical patterns (that generate clusters and networks) than on current economic pull factors (van der Gaag and van Wissen 2001). The validity of this instrument remains debatable, but it can be an effective method to predict skill-specific labour supply shocks in cities due to immigration (Card 2009 provides a good example for the US). Although the migrant stock is likely to be highly correlated with the current inflow, it is unlikely to be a good instrument since migrants cluster geographically in regions that have also grown faster historically. Meta-analyses suggest that IV estimation does generate larger impacts than OLS estimation (Longhi et al. 2005a, b).

\subsection{The assumed substitutability between immigrants and natives}

The political debate on the economic impact of immigration is partly driven by the belief that immigrants are close substitute for natives and, as predicted by the neoclassical model, are bound to generate negative externalities in terms of labour market opportunities of residents. Even when the local labour market is econometrically well defined, the issue of the extent to which immigrants are substitutes or complements to natives, earlier immigrants with the same characteristics (such as ethnicity) or different types of immigrants, remains a challenging empirical issue. A low degree of substitutability between natives and immigrants may be one reason why the literature has failed to find a large negative labour market impact of immigration. ${ }^{8}$

Studies such as Borjas (2003) assume that immigrants and natives in the same education and experience group are perfect substitutes, whereas the seminal studies by Grossman (1982) and Borjas (1987) assumed them to be imperfect substitutes. The immigrant population has had in the past much lower levels of education on average than the native population in many countries in which the research was conducted, such as in the US and in Europe. ${ }^{9}$ In that case, immigrants are likely to be substitutes for low-skilled natives, but complements for high-skill natives. A number of studies estimated the impact of the overall share of immigrants on labour market outcomes of low-skill natives (e.g., Altonji and Card 1991; Winter-Ebmer and Zweimuller 1996;

\footnotetext{
${ }^{8}$ Peri and Sparber (2009) note that in the US foreign-born workers specialize in occupations intensive in manual-physical labour skills, while the native born pursue jobs more intensive in communicationlanguage skills.

9 This is not the case in countries that select immigrants strongly on the basis of skills, such as Australia, Canada and New Zealand. A points-based selection and admission system, in which points are awarded for migrant skills and a minimum number of points is needed for a successful application, has also been adopted in the United Kingdom since 2008, while the Netherlands and Ireland offer fast track visas to some groups of professional immigrants.
} 
Johannsson and Weiler 2004) and find a proportionally larger impact of immigration that, however, applies only to a small proportion of natives (i.e., those with low skills). More recent studies partly relax the assumption of perfect substitutability and segment both immigrants and natives by skill (Dustmann et al. 2005; Card 2005), although in most cases regressions are still computed including all observations so that the results only inform on the average elasticity across skill groups.

If women's labour force participation is more elastic than men's, the estimated impact of immigration might differ by gender. Furthermore, it has been suggested that immigrants might be substitutes for low-skill natives and for women, but complements to highly skilled natives (Borjas 2003). Previous meta-analyses show that immigrants tend to have the same impact on wages of men and women (which is linked to a similar average elasticity of the demand curve), while the impact on employment is larger for women than for men (Longhi et al. 2005a, b). The latter result is not surprising given that the wage elasticity of labour supply may be around +0.2 for women, when compared with -0.1 for men (e.g., Borjas 2008).

A very robust conclusion is that immigrants seem to have a much larger impact on wages of other (earlier) immigrants rather than on natives (Longhi et al. 2005b). However, the impact on employment of earlier immigrants is similar to that on natives (Longhi et al. 2005a). This suggests a greater substitutability on the labour demand side within migrant groups than between migrants and natives, while the wage elasticity of labour supply may not differ much between natives and immigrants. In terms of statistical significance, the impact of immigration is generally much more precisely estimated when it focuses on natives (who usually greatly outnumber the immigrants), rather than when it focuses on immigrant groups themselves (Longhi et al. 2008). Moreover, it is still unclear whether immigrants from different source countries are close substitutes for each other, even within narrowly defined skill groups. Studies of economic integration suggest, for example, that there is a considerable difference in labour market outcomes of immigrants from English-speaking source countries when compared with those from other countries, all else being equal (e.g., Chiswick et al. 2008).

\section{The combined impact of immigration on wages and employment: a meta-analysis}

\subsection{Relationship between the impact on wages and on employment}

Here, we focus on the local-level impact of immigration, estimated by means of the area/spatial correlations approach outlined in Sect. 2.2. Some primary studies using the area approach have estimated the impact of immigration on both wages and employment with the same dataset, often in separate reduced form regressions.

The available studies for meta-analysis permit some conclusions regarding the impact of labour market flexibility. In an environment with a high degree of labour mobility and flexible wages (such as in the US), we would expect little wage variation and large native employment adjustment at the local level (through internal migration), while the wage impact at the national level will be a decline of 
real wages (particularly of close substitutes) but increases in employment due to the general equilibrium effects (unit cost declines lead for example to an increased volume of exports). In an economy with a low level of labour mobility and little national wage flexibility (such as in European countries), the wage impact at the local level will still be small but relatively larger than in the US (as Longhi et al. $2005 \mathrm{~b}$ found) and the negative effect on native employment may also be larger, if unemployment emerges and labour force participation of the native born declines (as suggested by Longhi et al. 2005a). At the national level, in an economy with a rigid labour market and a localised labour supply shock through immigration there will be little effect on wages and employment. The impact remains predominantly localised.

In all cases, the effects on earlier immigrants (who are close substitutes to the new arrivals) are likely to be much larger than on natives (as all previous meta-analyses confirmed). In a rigid national labour market, an immigration shock in a particular region will lower the wages of previous immigrants in that specific region (and increase employment of immigrants overall), but have little impact on wages and employment of immigrants nationally. In a flexible labour market, wages of immigrants in the directly affected region will not change much (due to outmigration of earlier immigrants from there), while employment of immigrants in that region will increase somewhat. At the national level, wages of immigrants in the flexible labour market will decrease, while both native and immigrant employment will increase.

Thus, in countries where wages are rather sticky (such as in Europe), the adjustment to a positive immigration shock may be in terms of (un-)employment and labour force participation. The same argument can be made with respect to changes in wage flexibility over time. When wages become more flexible, the wage impact of an immigration shock may increase, while the employment effect may decrease. These arguments suggest that on balance when the major exogenous variation across primary studies is the extent of wage flexibility across different countries or over time, we are more likely to observe that in studies where wage effects are large, employment effects are small and vice versa, i.e., a negative correlation. We use here meta-analysis to test this idea.

\subsection{Data}

We analyse whether there is a negative correlation between the impact of immigration on wages and employment by comparing seven primary studies that compute the impact of immigration on both wages and employment: four using US data (Altonji and Card 1991; Borjas et al. 1997; Card 2001, 2005) and three using data from Europe and Israel (Carrington and de Lima 1996; Winter-Ebmer and Zimmermann 1999; Cohen-Goldner and Paserman 2006). The studies, the number of effect sizes (elasticities) derived from these publications, the countries concerned and precision-weighted average effect sizes are reported in Table 2.

When the primary study proposes several model specifications, generally the authors show exactly the same model specifications using first wages and then employment as the dependent variable; hence, the pairing of wage and employment 
Table 2 Primary studies estimating the impact of immigration on wages and employment

\begin{tabular}{|c|c|c|c|c|c|c|}
\hline Reference & $\begin{array}{l}\text { Number } \\
\text { of effect } \\
\text { sizes }\end{array}$ & Country & $\begin{array}{l}\text { Wage } \\
\text { elasticity } \\
\text { minimum }\end{array}$ & $\begin{array}{l}\text { Wage } \\
\text { elasticity } \\
\text { maximum }\end{array}$ & $\begin{array}{l}\text { Employment } \\
\text { elasticity } \\
\text { minimum }\end{array}$ & $\begin{array}{l}\text { Employment } \\
\text { elasticity } \\
\text { maximum }\end{array}$ \\
\hline Altonji and Card (1991) & 20 & US & -1.910 & 1.213 & -0.279 & 0.658 \\
\hline Carrington and de Lima (1996) & 3 & Portugal & 0.006 & 0.009 & 0.000 & 0.000 \\
\hline Borjas et al. (1997) & 28 & US & -0.174 & 1.130 & -0.159 & 0.187 \\
\hline \multirow{2}{*}{$\begin{array}{l}\text { Winter-Ebmer and } \\
\text { Zimmermann (1999) }\end{array}$} & 4 & Austria & -0.164 & -0.081 & -0.042 & -0.001 \\
\hline & 4 & Germany & -0.067 & 0.028 & -0.008 & 0.470 \\
\hline Card (2001) & 28 & US & -0.251 & 0.063 & -0.202 & -0.007 \\
\hline Card (2005) & 2 & US & 0.006 & 0.010 & -0.013 & -0.012 \\
\hline $\begin{array}{l}\text { Cohen-Goldner and } \\
\text { Paserman (2006) }\end{array}$ & 40 & Israel & -1.548 & 0.922 & -0.203 & 0.087 \\
\hline Total & 129 & & & & & \\
\hline Simple average elasticity & & & Wage & -0.041 & Employment & +0.001 \\
\hline Median elasticity & & & Wage & -0.041 & Employment & -0.013 \\
\hline $\begin{array}{l}\text { Fixed effects estimator } \\
\text { of average elasticity }\end{array}$ & & & Wage & -0.029 & Employment & -0.011 \\
\hline $\begin{array}{l}\text { Random effects estimator } \\
\text { of average elasticity }\end{array}$ & & & Wage & -0.036 & Employment & -0.019 \\
\hline
\end{tabular}

estimates is often straightforward. The wage and employment effects are normally estimated independently using exactly the same data and the same econometric technique. Those few cases in which either the data or the econometric techniques used are similar, but not identical, have not been included in this analysis. The seven primary studies listed in Table 2 provide 129 effect sizes that can be used for our meta-analysis. ${ }^{10}$ The majority of effect sizes (78) refer to the US labour market; 40 refer to Israel, while the remaining 11 refer to three European countries (Portugal, Austria and Germany). The effect sizes refer to the percentage change in wages or employment following a $1 \%$ point increase in the share of immigrants in the labour market. For convenience, we refer to these effect sizes as the wage and employment elasticities, respectively, from here on. Among our sample, the wage elasticities vary between -1.910 and +1.213 ; while for employment the range is -0.279 to +0.658 (both pairs of extremes originating from Altonji and Card 1991).

In this sample, the average wage elasticity is negative and small -0.041 , while the average employment elasticity is positive and very small: +0.001 . The median wage elasticity coincides with the mean, -0.041 , while the median employment elasticity is -0.013 . However, such raw averages are not very meaningful because the standard errors vary considerably across the estimates. When the elasticities are weighted by the inverse of their variances (which corresponds to a standard fixed

\footnotetext{
${ }^{10}$ Borjas et al. (1997) estimated the impact of immigration on two measures of wages (weekly and annual wages). To avoid one of the wage estimations to be excluded from the meta-analysis we included the employment estimation twice, once paired with the estimations on weekly wages and once paired with the estimations on annual wages. Excluding one of these two groups of wage estimations does not change the results noticeably.
} 
effect model in meta-analysis, e.g., Sterne 2009) the average elasticity of wages reduces to -0.029 , while the average elasticity of employment becomes $-0.011 .^{11}$ The interpretation is that a $1 \%$ point increase in the immigration to population ratio reduces wages by only $0.03 \%$. This local labour market estimate is only about onethird of that found by Longhi et al. (2005b). Similarly, the employment effect is only one twentieth of that found in Longhi et al. (2005a). The localised wage and employment effects in the present sample of primary studies are very small indeed.

However, the test of homogeneity of the effect sizes is strongly rejected: the $Q$-statistic is 2051 for the wage elasticity and 828 for the employment elasticity (this statistic has with the present data 128 degrees of freedom). The estimates are drawn from different "populations", which is what we would expect given the different countries and periods considered. There are two ways of modelling this heterogeneity. One is to assume that the heterogeneity is random; the other is to identify study features that have an impact on the distribution of effect sizes. The former approach is called the random effects estimator; the latter is referred to as meta-regression analysis (MRA). Before considering MRA in the next two sub-sections, we report that the random effects estimator of the wage impact elasticity is -0.036 and of the employment elasticity -0.019 . These numbers are somewhat closer to the simple averages, as expected, and the random effects wage elasticity is about twice the employment elasticity, suggesting a local native labour supply elasticity of $-0.019 /-0.036=0.527$.

Figure 2 graphically shows the relationship between the pairs of effect sizes. It reports the estimated employment elasticity on the horizontal axis and the estimated wage elasticity on the vertical one. The correlation is weak, but negative, and the correlation coefficient is -0.138 . We shall see in the following text that once we move from a bivariate to a multivariate setting — with study characteristics forming the covariates - the partial effect of the wage elasticity on the employment elasticity is negative and statistically significant.

\subsection{Model}

We analyse the relationship between the impact of immigration on wages and employment by means of a system of two structural equations estimated by 3SLS. The first equation models the estimated percentage change in wages following a $1 \%$ point increase in the immigration share of population $\left({ }^{w} b_{i j}\right)$ as a function of characteristics of the primary studies and the corresponding estimated impact of immigration on employment $\left({ }^{e} b_{i j}\right)$, where $i$ indexes estimates and $j$ studies. The second equation models the estimated impact of immigration on employment as a function of characteristics of the primary studies and the estimated impact of immigration on wages; the disturbances of the two equations $\left(\varepsilon_{1 i j}\right.$ and $\left.\varepsilon_{2 i j}\right)$ are allowed to be correlated.

$$
\begin{aligned}
{ }^{w} b_{i j} & =\gamma_{1} e_{i j}^{b}+c_{i j}^{m c} \delta_{1}+{ }^{w} m_{i j}{ }^{w} \delta_{1}+\varepsilon_{1 i j} \\
{ }^{e} b_{i j} & =\gamma_{2}^{w} b_{i j}+{ }^{c} m_{i j}{ }^{c} \delta_{2}+{ }^{e} m_{i j}{ }^{e} \delta_{2}+\varepsilon_{2 i j}
\end{aligned}
$$

\footnotetext{
11 All estimations were carried out in Stata 10.1.
} 


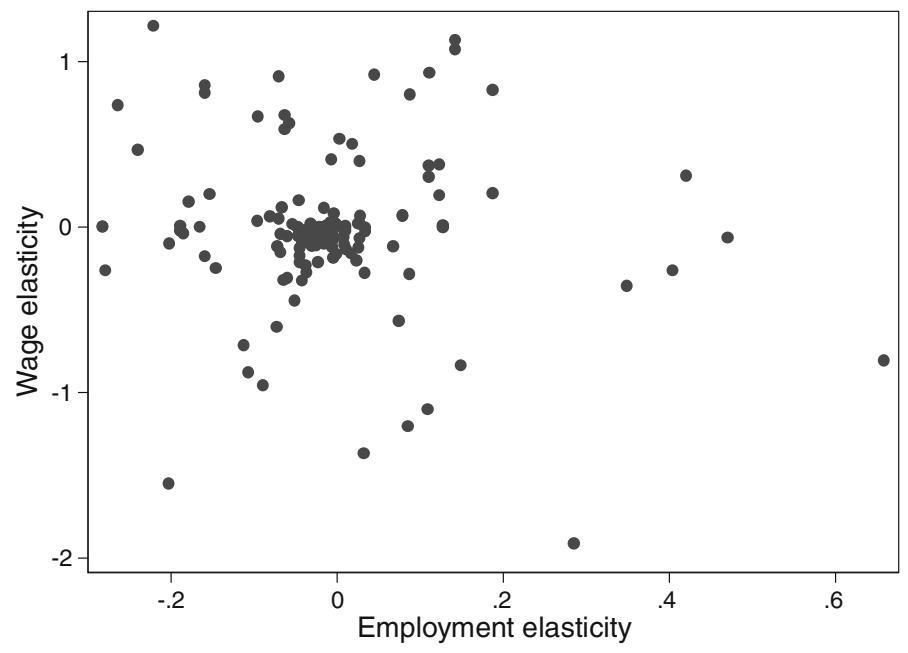

Fig. 2 Scatter plot of the employment and wage elasticities estimated by the primary studies

where ${ }^{w} b_{i j}$ and ${ }^{e} b_{i j}$ are the $i$ th estimates of the impact of immigration on wages and on employment, respectively, in the $j$ th primary study. As already mentioned, all primary studies included in this analysis interpret ${ }^{w} b_{i j}$ and ${ }^{e} b_{i j}$ as the impact that a $1 \%$ point increase in the share of immigration in population would have on wages and employment of natives. Those studies that would imply a different interpretation of ${ }^{w} b_{i j}$ and ${ }^{e} b_{i j}$ (e.g., Friedberg 2001) have not been included in this metasample. Finally, as already mentioned, those primary studies that compute ${ }^{w} b_{i j}$ and ${ }^{e} b_{i j}$ using slightly different data samples or slightly different econometric techniques have also been excluded from this meta-sample because we cannot be confident that ${ }^{w} b_{i j}$ and ${ }^{e} b_{i j}$ measure two sides of the same coin (as in Eq. 2).

We partially control for study heterogeneity by adding a number of explanatory variables, referred to in meta-analysis as moderator variables. While some are common to both equations $\left({ }^{c} \boldsymbol{m}_{i j}\right)$, others are specific to each of the two equations. Because when estimating the impact of immigration on wages, the available data might refer either to annual, monthly, weekly, hourly wages or might be left unspecified, ${ }^{w} \boldsymbol{m}_{i j}$ includes dummies for annual, monthly, weekly and unspecified wages, while hourly wages is used as reference category (see Table 3). Because of collinearity, however, only the dummies for annual and for weekly wages appear in the models. The explanatory variable specific to the second equation $\left({ }^{e} \boldsymbol{m}_{i j}\right)$ is a dummy for whether the impact of immigration on employment refers to total employment, as opposed to the employment rate, which is used as reference category.

The explanatory variables that are used in both equations $\left({ }^{c} \boldsymbol{m}_{i j}\right)$ are:

1. Two dummies for the definition of the labour market: one for whether the labour market has been defined using only skills and no geographical decomposition; the other for whether the labour market has been defined using 
Table 3 Descriptive statistics, number of effect sizes by study characteristic

\begin{tabular}{|c|c|c|}
\hline $\begin{array}{l}\text { Table } 3 \text { Descriptive statistics, } \\
\text { number of effect sizes by study } \\
\text { characteristic }\end{array}$ & & $\begin{array}{l}\text { Number of } \\
\text { effect sizes }\end{array}$ \\
\hline & Wage data: annual & 14 \\
\hline & Weekly & 8 \\
\hline & Hourly $^{\mathrm{a}}$ & 34 \\
\hline & Monthly & 68 \\
\hline & Unspecified & 5 \\
\hline & Employment data: total employment & 8 \\
\hline & Employment rate $^{\mathrm{a}}$ & 121 \\
\hline & Labour market: country-only skills & 43 \\
\hline & Geography and skills & 64 \\
\hline & Only geography ${ }^{\mathrm{a}}$ & 22 \\
\hline & Affected group: all immigrants & 14 \\
\hline & All natives or everybody ${ }^{\mathrm{a}}$ & 115 \\
\hline & Gender: men & 22 \\
\hline & Women & 22 \\
\hline & Men and women ${ }^{\mathrm{a}}$ & 85 \\
\hline & Country: US ${ }^{\mathrm{a}}$ & 78 \\
\hline & Israel & 40 \\
\hline & $\mathrm{EU}$ & 11 \\
\hline & Estimation: first differences & 46 \\
\hline & Levels $^{\mathrm{a}}$ & 83 \\
\hline & Estimation: IV & 30 \\
\hline & $\mathrm{OLS}^{\mathrm{a}}$ & 99 \\
\hline & Years of data: includes $1970 \mathrm{~s}$ & 34 \\
\hline & Includes $1980 \mathrm{~s}$ & 46 \\
\hline & Includes 1990s & 88 \\
\hline a Will be used as reference & Includes 2000s & 2 \\
\hline
\end{tabular}

Number of effect sizes

geography as well as other labour market characteristics such as occupations, education or skills. The reference category consists of those studies that decompose the labour market of the host country only into smaller geographical areas and not into skill groups (see Table 3).

2. One dummy identifying whether the impact of immigration is estimated for earlier immigrants. Because immigrants are generally only a small fraction of the population, the reference group includes all those effect sizes that estimate the impact of immigration on natives alone or on natives and immigrants together. ${ }^{12}$

3. A dummy for those effect sizes focusing on men only and one for those focusing on women only. The reference group refers to those effect sizes that do not make any gender distinction.

\footnotetext{
12 A separate dummy for those studies estimating the impact of immigration on natives alone would be dropped because of collinearity.
} 
4. One dummy for those studies estimating the impact of immigration on European countries, and one for those studies estimating the impact of immigration on Israel. The reference group includes those effect sizes estimating the impact of immigration on the US.

5. A dummy for those effect sizes computed using first differences versus using the levels of the data.

6. A dummy for those effect sizes using instrumental variables (IV) versus OLS.

7. A set of dummy variables for whether the data used to estimate the impact of immigration includes data for the 1970s, 1980s or 1990s. Since these dummies are not mutually exclusive, there is no need for a reference group here.

The number of effect sizes by moderator variables are summarised in Table 3.

To control for the heterogeneity of the effect sizes, we first estimate a metaregression model by 3SLS giving equal weight to each effect size. Second, we estimate the model after weighting each effect size by a measure of its precision. Although it is common in meta-analyses, we do not weight here by the inverse standard error of the effect size because two different effect sizes-with different standard errors-appear in each regression, one as dependent, and the other as explanatory variable (see Eq. 2). If we would weight by the precision of the estimates, then the same effect size would have different weights in the two equations. It would also be unclear whether the cross-elasticity (e.g., employment elasticity) should have the same weight as the dependent variable (e.g., wage elasticity). We believe a weighting scheme which gives the same weight to both equations is the most sensible choice. Hence, we weight instead by the square root of the sample size, which is common to both ${ }^{w} b_{i j}$ and ${ }^{e} b_{i j}$. Finally, we estimate more parsimonious models in which the moderator variables that were consistently statistically insignificant are excluded.

One issue that is often raised in meta-analysis is the extent to which the available effect sizes are representative of all studies that have been undertaken or whether statistically insignificant results may have ended up in a file drawer rather than having been reported. Formal tests of the presence of publication bias in reported wage and employment elasticities showed no clear evidence of such bias (Longhi et al. 2005a, b). Consequently, we will not further investigate the matter here.

\subsection{Results}

The results of the 3SLS regression model including all moderator variables are shown in Table 4. Block (1) shows estimations in which each effect size is given equal weight (3SLS model), while Block (2) shows estimations in which the square root of the sample size is used as weights (3SWLS model). The Hansen-Sargan test for overidentifying restrictions, computed as in Baum et al. (2006), is rejected for the 3SWLS model, but not for the 3SLS model. Many coefficients are statistically insignificant but the results seem rather consistent across the two specifications. For comparison, Block (3) shows single equation OLS estimates.

Table 4 suggests that less negative estimates of the impact of immigration on wages are associated with more negative estimates of the impact of immigration on 
Table 4 Meta-regressions-full model

\begin{tabular}{|c|c|c|c|c|c|c|}
\hline \multirow[b]{2}{*}{ Dependent variable } & \multicolumn{2}{|l|}{ (1) $3 \mathrm{SLS}$} & \multicolumn{2}{|c|}{ (2) 3 SWLS } & \multicolumn{2}{|c|}{ (3) Single equation OLS } \\
\hline & $\begin{array}{l}\text { Wage } \\
\text { elasticity }\end{array}$ & $\begin{array}{l}\text { Employment } \\
\text { elasticity }\end{array}$ & $\begin{array}{l}\text { Wage } \\
\text { elasticity }\end{array}$ & $\begin{array}{l}\text { Employment } \\
\text { elasticity }\end{array}$ & $\begin{array}{l}\text { Wage } \\
\text { elasticity }\end{array}$ & $\begin{array}{l}\text { Employment } \\
\text { elasticity }\end{array}$ \\
\hline Cross-elasticity: wage & & $\begin{array}{l}-0.406^{* * *} \\
(0.110)\end{array}$ & & $\begin{array}{l}-0.366^{* * *} \\
(0.129)\end{array}$ & & $\begin{array}{c}-0.006 \\
(0.031)\end{array}$ \\
\hline Employment & $\begin{array}{r}-11.759 \\
(16.001)\end{array}$ & & $\begin{array}{l}-8.007 \\
(13.759)\end{array}$ & & $\begin{array}{l}0.720 * * \\
(0.300)\end{array}$ & \\
\hline $\begin{array}{l}\text { Labour market: } \\
\text { only skills }\end{array}$ & 0.784 & $0.485 * * *$ & 0.995 & $0.433 * *$ & $1.215 * * *$ & 0.041 \\
\hline [Ref: only geography] & $(0.905)$ & $(0.156)$ & $(0.619)$ & $(0.177)$ & $(0.187)$ & $(0.074)$ \\
\hline Geography and skills & $\begin{array}{r}-0.225 \\
(1.289)\end{array}$ & $\begin{array}{l}0.216^{* *} \\
(0.095)\end{array}$ & $\begin{array}{c}0.149 \\
(1.006)\end{array}$ & $\begin{array}{c}0.197 * \\
(0.119)\end{array}$ & $\begin{array}{l}0.668 * * * \\
(0.148)\end{array}$ & $\begin{array}{c}0.001 \\
(0.053)\end{array}$ \\
\hline $\begin{array}{l}\text { Affected group: } \\
\text { all immigrants }\end{array}$ & 0.347 & 0.012 & 0.170 & 0.009 & -0.068 & $0.069 *$ \\
\hline [Ref: all Natives] & $(0.678)$ & $(0.060)$ & $(0.451)$ & $(0.053)$ & $(0.111)$ & $(0.039)$ \\
\hline $\begin{array}{l}\text { Gender: men } \\
\text { [Ref: men and women] }\end{array}$ & $\begin{array}{c}0.822 \\
(1.378)\end{array}$ & $\begin{array}{c}0.002 \\
(0.079)\end{array}$ & $\begin{array}{c}0.423 \\
(0.999)\end{array}$ & $\begin{array}{c}0.013 \\
(0.091)\end{array}$ & $\begin{array}{r}-0.176 \\
(0.132)\end{array}$ & $\begin{array}{l}0.145^{* * *} \\
(0.048)\end{array}$ \\
\hline Women & $\begin{array}{c}0.802 \\
(1.145)\end{array}$ & $\begin{array}{c}0.054 \\
(0.072)\end{array}$ & $\begin{array}{c}0.450 \\
(0.941)\end{array}$ & $\begin{array}{c}0.032 \\
(0.088)\end{array}$ & $\begin{array}{c}0.001 \\
(0.131)\end{array}$ & $\begin{array}{l}0.130 * * * \\
(0.047)\end{array}$ \\
\hline $\begin{array}{l}\text { Country: Israel } \\
\text { [Ref: US] }\end{array}$ & $\begin{array}{c}-0.232 \\
(0.940)\end{array}$ & $\begin{array}{c}-0.294^{*} \\
(0.157)\end{array}$ & $\begin{array}{c}-0.354 \\
(0.783)\end{array}$ & $\begin{array}{c}-0.236 \\
(0.166)\end{array}$ & $\begin{array}{l}-0.755^{* * *} \\
(0.172)\end{array}$ & $\begin{array}{l}0.185^{* * *} \\
(0.069)\end{array}$ \\
\hline $\mathrm{EU}$ & $\begin{array}{r}-2.460 \\
(4.033)\end{array}$ & $\begin{array}{c}-0.331 \\
(0.217)\end{array}$ & $\begin{array}{r}-1.712 \\
(3.723)\end{array}$ & $\begin{array}{r}-0.291 \\
(0.309)\end{array}$ & $\begin{array}{l}0.618 * * * \\
(0.235)\end{array}$ & $\begin{array}{c}0.144 \\
(0.123)\end{array}$ \\
\hline $\begin{array}{l}\text { Estimation: } \\
\text { first differences }\end{array}$ & 3.602 & 0.122 & 2.077 & 0.121 & $-0.442 * *$ & $0.263 * * *$ \\
\hline [Ref: levels] & $(5.213)$ & $(0.108)$ & $(4.216)$ & $(0.136)$ & $(0.174)$ & $(0.069)$ \\
\hline $\begin{array}{l}\text { IV } \\
\text { [Ref: OLS] }\end{array}$ & $\begin{array}{c}-1.464 \\
(1.750)\end{array}$ & $\begin{array}{l}-0.204 * * * \\
(0.066)\end{array}$ & $\begin{array}{c}-0.724 \\
(1.052)\end{array}$ & $\begin{array}{c}-0.125^{* *} \\
(0.056)\end{array}$ & $\begin{array}{r}-0.127 \\
(0.097)\end{array}$ & $\begin{array}{c}-0.031 \\
(0.033)\end{array}$ \\
\hline Years of the data: $1970 \mathrm{~s}$ & $\begin{array}{r}-0.296 \\
(0.777)\end{array}$ & $\begin{array}{r}-0.120 \\
(0.106)\end{array}$ & $\begin{array}{r}-0.207 \\
(0.765)\end{array}$ & $\begin{array}{r}-0.101 \\
(0.131)\end{array}$ & $\begin{array}{c}-0.615^{* * *} \\
(0.173)\end{array}$ & $\begin{array}{r}-0.076 \\
(0.072)\end{array}$ \\
\hline $1980 \mathrm{~s}$ & $\begin{array}{c}0.714 \\
(2.211)\end{array}$ & $\begin{array}{r}-0.148 * \\
(0.082)\end{array}$ & $\begin{array}{c}0.291 \\
(1.826)\end{array}$ & $\begin{array}{c}-0.109 \\
(0.097)\end{array}$ & $\begin{array}{c}-0.973 * * * \\
(0.121)\end{array}$ & $\begin{array}{c}0.016 \\
(0.049)\end{array}$ \\
\hline 1990s & $\begin{array}{r}-1.948 \\
(2.008)\end{array}$ & $\begin{array}{c}-0.327^{* * *} \\
(0.121)\end{array}$ & $\begin{array}{r}-1.402 \\
(1.614)\end{array}$ & $\begin{array}{c}-0.296^{* *} \\
(0.146)\end{array}$ & $\begin{array}{c}-0.491 * * \\
(0.200)\end{array}$ & $\begin{array}{r}-0.110 \\
(0.074)\end{array}$ \\
\hline $\begin{array}{l}\text { Wage data: annual } \\
\text { [Ref: hourly] }\end{array}$ & $\begin{array}{r}-3.492 \\
(6.100)\end{array}$ & & $\begin{array}{r}-1.828 \\
(4.814)\end{array}$ & & $\begin{array}{l}1.258 * * * \\
(0.232)\end{array}$ & \\
\hline Weekly & $\begin{array}{r}-3.366 \\
(5.943)\end{array}$ & & $\begin{array}{r}-1.745 \\
(4.659)\end{array}$ & & $\begin{array}{l}1.216^{* * *} \\
(0.219)\end{array}$ & \\
\hline $\begin{array}{l}\text { Employment data: } \\
\text { total employment }\end{array}$ & & 0.310 & & 0.200 & & -0.151 \\
\hline [Ref: employment rate] & & $(0.221)$ & & $(0.312)$ & & $(0.128)$ \\
\hline Intercept & $\begin{array}{c}1.266 \\
(1.776)\end{array}$ & $\begin{array}{l}0.116 \\
(0.104)\end{array}$ & $\begin{array}{c}0.640 \\
(1.233)\end{array}$ & $\begin{array}{l}0.070 \\
(0.110)\end{array}$ & $\begin{array}{c}0.014 \\
(0.195)\end{array}$ & $\begin{array}{c}-0.125^{* *} \\
(0.058)\end{array}$ \\
\hline
\end{tabular}


Table 4 continued

\begin{tabular}{|c|c|c|c|c|c|c|}
\hline \multirow[b]{2}{*}{ Dependent variable } & \multicolumn{2}{|l|}{ (1) $3 \mathrm{SLS}$} & \multicolumn{2}{|c|}{ (2) 3 SWLS } & \multicolumn{2}{|c|}{ (3) Single equation OLS } \\
\hline & $\begin{array}{l}\text { Wage } \\
\text { elasticity }\end{array}$ & $\begin{array}{l}\text { Employment } \\
\text { elasticity }\end{array}$ & $\begin{array}{l}\text { Wage } \\
\text { elasticity }\end{array}$ & $\begin{array}{l}\text { Employment } \\
\text { elasticity }\end{array}$ & $\begin{array}{l}\text { Wage } \\
\text { elasticity }\end{array}$ & $\begin{array}{l}\text { Employment } \\
\text { elasticity }\end{array}$ \\
\hline Hansen-Sargan test & & 0.029 & & $8.382 * * *$ & & \\
\hline$P$-value & & 0.865 & & 0.004 & & \\
\hline $\begin{array}{l}\text { Correlation between } \\
\text { observed and } \\
\text { predicted effect sizes }\end{array}$ & 0.136 & 0.352 & 0.224 & 0.369 & 0.799 & 0.623 \\
\hline
\end{tabular}

The total number of observations is 129. The estimation method is 3SLS. 3SWLS: effect sizes are weighted by the square root of the number of observations in the primary study. Hansen-Sargan is the test for over-identifying restrictions (see Davidson and MacKinnon 2004). Robust standard errors are given in parenthesis. $*$ Indicates significant at $10 \%$, ** significant at $5 \%$, and $* * *$ significant at $1 \%$

employment. However, the wage elasticity seems rather insensitive to changes in the employment elasticity: although the regression coefficients of ${ }^{e} b_{i j}$ are large and negative in Blocks (1) and (2), they are not statistically significant. We therefore draw the plausible conclusion that wage rigidity increases the magnitude of a decline in employment of the native born, following a positive net immigration shock. On the other hand, observed employment elasticities appear less informative about whether larger or smaller wage effects may be expected. The causation seems to go from wages to employment, but not vice versa.

When more recent data are used, the estimated impact of immigration seems to be larger. This might be due to different reasons. More recent studies, for which better data and econometric techniques are available, might be better able to identify a negative impact of immigration. However, it is also possible that the impact of immigration might change over time and might have become larger in more recent years. More research is needed to verify whether the impact of immigration is increasing in recent years or whether the estimated increase is an econometric artefact.

A change in the hourly wage may lead to a response in hours worked that is either in the same direction (upward sloping individual labour supply curve) or in the opposite direction (backward bending labour curve). The time scale of the measurement of wages may therefore affect the coefficient of the immigrant share variable in wage regressions. However, the 3SLS and 3SWLS meta-regressions show that there is no statistically significant difference between elasticities computed with hourly wages, when compared with wages calculated over longer periods. With OLS, the longer term earnings impact is less negative than the hourly wage impact, consistent with backward bending labour supply behaviour.

The effect size of the impact of immigration on employment is less likely to be negative when skills are taken into account in the definition of the local labour market. The results also suggest that after correcting for the cross-elasticity immigrants seem to have the same impact on natives and earlier immigrants and that the impact does not seem to differ by gender. Also, immigration seems to have a 
more negative impact on employment in Israel than on the EU or the US. While those effect sizes estimated using first differences do not seem to differ from those estimated using level data, using instrumental variables approaches leads to the estimation of larger negative employment impacts of immigration.

As noted earlier, the last two columns of Table 4 show the results of a model of single independent equations estimated by OLS. The single equation models suggest, rather counter-intuitively, that a larger elasticity of employment would imply a larger estimated wage elasticity but that the wage elasticity would not have any impact on the estimated elasticity of employment.

Table 5 shows the results of a more parsimonious model in which the moderator variables that were consistently statistically insignificant in Table 4 are excluded from the model. Also in this case, the Hansen-Sargan test for overidentifying restrictions is rejected for the 3SWLS model, but the results are rather robust across the two specifications. The models confirm the previous finding of a negative relationship between the impact of immigration on wages and the impact of immigration on employment. Again, the impact of immigration is less likely to be negative when skills are taken into account in the definition of the local labour market, but more negative when instrumental variables approaches are used. Furthermore, the results also show that in the EU the impact of immigration on wages is less negative than in the US, but the impact of immigration on employment is larger. This is consistent with the earlier meta-analyses and with the general idea that in labour market with relative rigid wages, adjustments to exogenous shocks may be primarily in terms of employment.

\section{Sources of productivity impacts of immigration}

The meta-analytic evidence provided in Sect. 4.2 suggests that the wage and employment effects of a positive immigration shock in the local labour market are very small indeed. Besides wage and employment effects of immigration that we have quantitatively summarised in this paper, comprehensive impact studies should also take into account the impact across a wide range of other domains: demographic, economic, fiscal, social, cultural, environmental, etc. Such impact studies have been conducted at the national level (e.g., Smith and Edmonston 1997 for the US). Impacts across a wide range of areas are also reviewed by Hanson (2008); Pekkala Kerr and Kerr (2008); and Poot and Cochrane (2005). However, such reviews focus predominantly on the national level and do not explicitly consider the spatial distribution of the impact. A full review of the issues would be beyond the scope of the present paper, but we will outline a few aspects that link to local labour market effects and that may have important implications for the longrun impact of immigration on the wellbeing of the host population. For an overview of the broader impacts on US cities, see Card (2007).

The first of these issues is the extent to which an immigration influx in a particular region triggers an internal migration response of either the native born or of other groups of immigrants. Okkerse (2008) and Hanson (2008) note that the evidence is inconclusive. For example, Borjas (2006) finds that in the US high 
Table 5 Meta-regressions-reduced model

\begin{tabular}{|c|c|c|c|c|}
\hline \multirow[b]{2}{*}{ Dependent variable } & \multicolumn{2}{|l|}{ (1) $3 \mathrm{SLS}$} & \multicolumn{2}{|l|}{ (2) $3 \mathrm{SWLS}$} \\
\hline & $\begin{array}{l}\text { Wage } \\
\text { elasticity }\end{array}$ & $\begin{array}{l}\text { Employment } \\
\text { elasticity }\end{array}$ & $\begin{array}{l}\text { Wage } \\
\text { elasticity }\end{array}$ & $\begin{array}{l}\text { Employment } \\
\text { elasticity }\end{array}$ \\
\hline Cross-elasticity: wage & & $\begin{array}{c}-0.365 * * * \\
(0.107)\end{array}$ & & $\begin{array}{c}-0.327 * * * \\
(0.119)\end{array}$ \\
\hline Employment & $\begin{array}{c}0.833 \\
(0.746)\end{array}$ & - & $\begin{array}{c}0.380 \\
(1.532)\end{array}$ & \\
\hline $\begin{array}{l}\text { Labour market: only skills } \\
\text { [Ref: only geography] }\end{array}$ & $\begin{array}{l}1.142 * * * \\
(0.166)\end{array}$ & $\begin{array}{l}0.468 * * * \\
(0.150)\end{array}$ & $\begin{array}{l}1.127 * * * \\
(0.186)\end{array}$ & $\begin{array}{l}0.425^{* * *} \\
(0.163)\end{array}$ \\
\hline Geography and skills & $\begin{array}{l}0.600 * * * \\
(0.119)\end{array}$ & $\begin{array}{l}0.222 * * * \\
(0.085)\end{array}$ & $\begin{array}{l}0.599 * * * \\
(0.162)\end{array}$ & $\begin{array}{l}0.210 * * \\
(0.106)\end{array}$ \\
\hline Country: Israel & $-0.684 * * *$ & $-0.296 * * *$ & $-0.633 * * *$ & $-0.237 * *$ \\
\hline [Ref: US] & $(0.127)$ & $(0.115)$ & $(0.107)$ & $(0.103)$ \\
\hline EU & $\begin{array}{l}0.599 * * \\
(0.253)\end{array}$ & $\begin{array}{c}-0.455^{* * * *} \\
(0.140)\end{array}$ & $\begin{array}{c}0.451 \\
(0.413)\end{array}$ & $\begin{array}{r}-0.420 * \\
(0.220)\end{array}$ \\
\hline IV & $-0.236 * * *$ & $-0.182 * * *$ & -0.145 & $-0.114 * *$ \\
\hline [Ref: OLS] & $(0.086)$ & $(0.067)$ & $(0.115)$ & $(0.055)$ \\
\hline Years of the data: $1970 \mathrm{~s}$ & $\begin{array}{l}-0.864 * * * \\
(0.204)\end{array}$ & $\begin{array}{r}-0.013 \\
(0.081)\end{array}$ & $\begin{array}{c}-0.756^{* *} \\
(0.369)\end{array}$ & $\begin{array}{r}-0.003 \\
(0.096)\end{array}$ \\
\hline $1980 \mathrm{~s}$ & $\begin{array}{c}-1.127 * * * \\
(0.201)\end{array}$ & $\begin{array}{r}-0.058 \\
(0.066)\end{array}$ & $\begin{array}{c}-0.970 * * \\
(0.408)\end{array}$ & $\begin{array}{r}-0.018 \\
(0.060)\end{array}$ \\
\hline $1990 \mathrm{~s}$ & $\begin{array}{c}-0.733 * * * \\
(0.171)\end{array}$ & $\begin{array}{c}-0.251 * * \\
(0.122)\end{array}$ & $\begin{array}{c}-0.702 * * * \\
(0.225)\end{array}$ & $\begin{array}{r}-0.232 \\
(0.142)\end{array}$ \\
\hline Wage data: annual & $0.985 * * *$ & & $0.898 * *$ & \\
\hline [Ref: hourly] & $(0.196)$ & & $(0.389)$ & \\
\hline Weekly & $\begin{array}{l}0.986 * * * \\
(0.198)\end{array}$ & & $\begin{array}{l}0.897 * * \\
(0.398)\end{array}$ & \\
\hline Employment data: total employment & & $0.444 * * *$ & & 0.347 \\
\hline [Ref: employment rate] & & $(0.145)$ & & $(0.225)$ \\
\hline Intercept & $\begin{array}{c}0.258 * \\
(0.147)\end{array}$ & $\begin{array}{c}0.061 \\
(0.085)\end{array}$ & $\begin{array}{c}0.156 \\
(0.180)\end{array}$ & $\begin{array}{c}0.018 \\
(0.086)\end{array}$ \\
\hline Hansen-Sargan test & & 0.069 & & $4.197 * *$ \\
\hline$P$-value & & 0.793 & & 0.040 \\
\hline $\begin{array}{l}\text { Correlation between observed and } \\
\text { predicted effect sizes }\end{array}$ & 0.768 & 0.348 & 0.774 & 0.367 \\
\hline
\end{tabular}

The total number of observations is 129. The estimation method is 3SLS. 3SWLS: effect sizes are weighted by the square root of the number of observations in the primary study. Hansen-Sargan is the test for over-identifying restrictions (see Davidson and MacKinnon 2004). Robust standard errors are given in parenthesis. $*$ Indicates significant at $10 \%$, ** significant at $5 \%$, and *** significant at $1 \%$

immigration areas are associated with lower native in-migration rates and higher out-migration rates. Hatton and Tani (2005) draw a similar conclusion with UK data. However, Card (2005) concludes that mobility flows of natives and earlier immigrants are not very sensitive to inflows of new immigrants. Given that the level 
of geographical mobility is much higher in North America and Australasia than in Europe, the mechanism of adjustment through internal migration may be expected to be less in Europe in any case.

A second issue is the effect of immigration on the local price level. If immigrants increase the labour supply in local services (such as housekeeping and gardening), the price of such services (and the wages of those working in this sector) may decrease. This downward effect on the local price level can offset the downward effect on real disposable income associated with small wage declines following immigration. Cortes (2008) finds indeed such effects of low-skilled immigration on prices across US cities. Lach (2007) finds that a large influx of immigrants from the former Soviet Union (FSU) to Israel in 1990 also reduced prices in that country.

An effect of immigration that may counteract the downward impact on some prices may be the impact on the demand for housing, given scarcity of land and the relatively inelastic supply of housing units, particularly in the short-run. Saiz (2003) used the natural experiment of the Mariel boatlift to assess rental housing market effects and found that rents of the lower quality housing units increased sharply, thereby generating a negative real wage effect even when nominal wages did not change. However, Card (2007) finds that because wages of natives rise on average due to immigration (essentially they are complements to immigrants at the aggregate level), the average "rent burden" (the ratio of rent to income) does not change.

Generally, it is again important to distinguish between the short-run and the longrun (see also Table 1). Even if real wages decline in a regional labour market in the short-run, this short-run cost may be quickly offset by long-run gains if there are permanent productivity gains triggered by immigration. Although this is clearly one of the most important issues in a comprehensive impact analysis of immigration, very little is known to date about the effects of immigration and of population ageing, which is the other important demographic trend around the world, on the long-run growth path of the national or regional economy (Poot 2008).

An important effect through which immigration can raise productivity in the host region is that the presence of additional workers, skilled or unskilled, raises the rate of return to capital. While on the one hand, the greater endowment of labour may encourage firms to resist investing in labour saving technology, on the other the expanding local economy will require a greater capital stock and the new vintages of capital will be more productive than the old. In a growth accounting exercise over the period 1960-2006 for 50 US states, Peri (2008) finds that the capital-labour ratio does not decline with increased immigration and that immigration significantly increases the productivity of workers of all skills. Similarly, Peri (2009) argues that immigrants promote efficient task specialisation and the adoption of unskilled-biased technology. His estimates suggest that an increase in employment in a US state of $1 \%$ due to immigration yields an increase in income per worker of $0.5 \%$ in that state.

What could be the cause of such productivity growth? One possibility is that the economy is on an endogenous growth path, with an exogenous immigration shock boosting growth through increasing returns (e.g., by means of scale or population density effects). In addition, highly skilled immigrants may have positive spillovers for innovation in the economy. Hunt and Gauthier-Loiselle (2008) find that immigrant post-college graduates and scientists boost the level of patenting in the 
US and that there is a positive spillover to native inventors. Similarly, Chellaraj et al. (2008) find that the presence of foreign graduate students has a significant and positive impact on patent applications and patents awarded in the US by universities and other organisations. Partridge and Furtan (2008) find with Canadian provincial data that skilled immigrants (also proficient in either English or French) have a significant and positive impact on innovation in the province they live in.

However, many countries experience inward migration of semi-skilled or unskilled workers. In these cases, we would not expect direct spillover benefits to innovation but a number of other productivity-enhancing mechanisms may still be in force, even besides technological change associated with investment acceleration that was already noted. Productivity enhancements may also result from positive self-selection of the migrants in terms of creativity and entrepreneurial ability and the effects of increasing diversity of the local population.

Even the psychology literature suggests positive effects of immigration on creativity. Maddux and Galinsky (2009) find that living abroad increases creativity. This effect may well lead to innovative practices among migrant entrepreneurs. In recent years, much research has been conducted on the incidence and determinants of migrant entrepreneurship in Europe, the US and globally (e.g., Kloosterman and Rath 2003; Baycan-Levent and Nijkamp 2007; Constant et al. 2007).

A further contribution of migration to endogenous growth could be the spatial clustering, which is commonly observed for many migrant groups. The more intensive clustering of migrant groups appears associated with the growing ethnic and cultural diversity of immigrants vis-à-vis the host population (Cutler et al. 2008). Recent research suggests that some migrant clustering may improve socio-economic outcomes in the clusters themselves, but too much segregation is harmful (de Graaff and Nijkamp 2009). However, an important question from the perspective of immigration impacts assessment remains as yet unanswered: to what extent is the spatial configuration of migrant settlement optimal from the perspective of the host population, taking into account the various economic and social externalities?

Through being different from the host population in terms of a range of characteristics, inward migration increases diversity in host regions. Research has been focussing in recent years on the impact of cultural diversity on national and regional outcomes, following an influential review by Alesina and La Ferrara (2005). Ottaviano and Peri (2006) and Bellini et al. (2008) provide evidence for US cities and European regions, respectively, that migrant diversity generates consumption and production externalities that in net terms generate a causal link from migrant diversity to productivity.

Finally, another channel through which migrant diversity can improve productivity and long-run growth is the extent to which immigration facilitates international trade and contributes to export-driven growth. The net effect on trade is not obvious. For example, the literature suggests that immigration may boost exports and inward tourism less than imports and outward tourism (for a recent review, see Strutt et al. 2008). Nonetheless, greater population diversity induced by immigration increases the gains from international trade. However, greater diversity may also imply greater social costs. Card et al. (2009) find that individual attitudes towards immigration reflect a combination of concerns over conventional economic 
impacts (such as wages and employment as discussed in this paper) and concerns over the extent to which immigration can erode traditional values and homogeneity. Using data from the European social survey (ESS), they find that people give the latter much more weight than the former. The paradox of increasing diversity yielding greater economic benefits and greater social costs suggests that in regions where immigration is used as an instrument for long-run development, policies to promote post-settlement integration and multiculturalism are essential elements of a sustainable growth strategy.

\section{Conclusion}

In this paper, we reviewed the impact of immigration on the labour market, particularly from the local labour market perspective. Using a meta-analytic approach, we found that the wage and employment effects of an immigration shock are very small. Using a weighted average with weights determined by the precision of the estimate, we found that a $1 \%$ point increase in the share of immigrants in the local labour market of a typical host country decreases wages of the native born by $0.029 \%$ and decreases employment of the native born by $0.011 \%$. The magnitudes of the elasticities are smaller than those found in previous meta-analyses (Longhi et al. 2005a, b) that included a larger number of national level estimates. Hence, the results are not surprising because we would expect localised effects to be smaller than the national effects.

However, there is considerable heterogeneity among the studies. Wage rigidity increases the magnitude of the employment impact on the native born. Given the relationship between the wage elasticity and the employment elasticity with respect to the native born via the labour supply elasticity of the latter, an inverse cross-study correlation between wage and employment effects is not surprising: in the open local labour market the supply of the native born is rather elastic (as they can migrate out), and the wage impact is therefore muted while the magnitude of the effect on employment of the native born would be somewhat larger. However, the metaanalysis shows that the definition of the local labour market in terms of geography and skills matters. Moreover, the employment impact is more pronounced in Europe than in the United States. Finally, controls for endogeneity of the immigration shock by means of IV estimation show a somewhat more negative impact.

There are many channels through which an open labour market can absorb a labour supply shock and yield the small empirical elasticities reported in this paper. Besides labour force participation and internal migration responses, these would include investment, price level, demand and industry composition, innovation and productivity effects. These were briefly reviewed. The literature on these effects is only just emerging and much remains to be done. Moreover, a comprehensive multiregional general equilibrium approach of a spatially specific immigration shock is yet to be undertaken. While it is broadly agreed that there are net economic gains from immigration, only such a dynamic general equilibrium approach will permit an assessment of the distributional impacts: spatially, temporally and across native and immigrant households. 
Open Access This article is distributed under the terms of the Creative Commons Attribution Noncommercial License which permits any noncommercial use, distribution, and reproduction in any medium, provided the original author(s) and source are credited.

\section{References}

Addison T, Worswick C (2002) The impact of immigration on the earnings of natives: evidence from Australian micro data. Econ Rec 78:68-78

Akbari AH, Devoretz DJ (1992) The substitutability of foreign-born labour in Canadian-production: circa 1980. Can J Econ 25:604-614

Alesina A, La Ferrara E (2005) Ethnic diversity and economic performance. J Econ Lit 43:762-800

Altonji JG, Card D (1991) The effect of immigration on the labor market outcomes of less-skilled natives. In: Abowd JM, Freeman RB (eds) Immigration, trade and the labor market. University of Chicago Press, Chicago, pp 201-234

Angrist JD, Kugler A (2003) Protective or counter-productive? Labor market institutions and the effect of immigration on EU natives. Econ J 113:F302-F331

Anselin L, Le Gallo J, Jayet H (2008) Spatial panel econometrics. In: Matyas L, Severstre P (eds) The econometrics of panel data: fundamentals and recent developments in theory and practice. Springer, Berlin

Aydemir A, Borjas GJ (2007) Cross-country variation in the impact of international migration: Canada, Mexico, and the United States. J Eur Econ Assoc 5:663-708

Baas T, Brücker H (2010) Macroeconomic impact of Eastern enlargement on Germany and UK: evidence from a CGE model. Appl Econ Lett 17:125-128

Barret A, Bergin A, Duffy D (2005) The labour market characteristics and labour market impacts of immigrants in Ireland. IZA discussion paper no. 1553. IZA Institute for the Study of Labor, Bonn

Bauer T (1998) Do immigrants reduce natives' wages? Evidence from Germany. Department of Economics, Rutgers University working paper no. 1998/02

Baum CF, Schaffer ME, Stillman S, Wiggins V (2006) Overid: Stata module to calculate tests of overidentifying restrictions after ivreg, ivreg2, ivprobit, ivtobit, reg3. http://ideas.repec.org/c/boc/ bocode/s396802.html. Accessed 28 Aug 2009

Baycan-Levent T, Nijkamp P (2007) Migrant entrepreneurship in a diverse Europe: in search of sustainable development. Research Memorandum 2007-11. Department of Spatial Economics, VU University, Amsterdam

Bean FD, Lowell BL, Taylor LJ (1988) Undocumented Mexican immigrants and the earnings of other workers in the United States. Demography 25:35-52

Bellini E, Ottaviano GIP, Pinelli D, Prarolo G (2008) Cultural diversity and economic performance: evidence from European regions. HWWI Research Paper 3-14, Hamburg Institute of International Econ

Bhagwati J (1976) The brain-drain and taxation: theory and empirical analysis. North Holland, New York Bommes M, Morawska E (eds) (2005) International migration research. Ashgate, Aldershot

Borjas GJ (1987) Immigrants, minorities, and labor market competition. Ind Labor Relat Rev 40:382-392

Borjas GJ (1999) The economic analysis of immigration. In: Ashenfelter O, Card D (eds) Handbook of labor economics, vol 3A. North Holland, Amsterdam, pp 1697-1760

Borjas GJ (2003) The labor demand curve is downward sloping: reexamining the impact of immigration on the labor market. Q J Econ 118:1335-1374

Borjas GJ (2006) Native internal migration and the labor market impact of immigration. J Hum Resour 41:221-258

Borjas GJ (2008) Labor economics, 4th edn. McGraw-Hill Irwin, New York

Borjas GJ (2009) The analytics of the wage effect of immigration. NBER Working Paper 14796, National Bureau of Economic Research

Borjas GJ, Freeman RB, Katz LF (1992) On the labor market effects of immigration and trade. In: Borjas GJ, Freeman RB (eds) Immigration and the work force: economic consequences for the United States and source areas. National Bureau of Economic Research, University of Chicago Press, Chicago, pp 246-251

Borjas GJ, Freeman RB, Katz LF (1996) Searching for the effect of immigration on the labor market. Am Econ Rev 86:246-251 
Borjas GJ, Freeman RB, Katz LF (1997) How much do immigration and trade affect labor market outcomes? Brook Pap Econ Act 1:1-90

Borjas GJ, Grogger J, Hanson GH (2008) Imperfect substitution between immigrants and natives: a reappraisal. NBER working paper no. 13887, National Bureau of Economic Research, Cambridge

Bryant J, Rukumnuaykit P (2007) Does immigration to Thailand reduce the wages of Thai workers? mimeo. Institute for Population and Social Research, Mahidol University, Thailand

Card D (1990) The impact of the Mariel boatlift on the Miami labor market. Ind Labor Relat Rev 43: 245-257

Card D (2001) Immigrant inflows, native outflows, and the local market impacts of higher immigration. J Labor Econ 19:22-64

Card D (2005) Is the new immigration really so bad? Econ J 115:F300-F323

Card D (2007) How immigration affects U.S. cities. CReAM discussion paper no 11/07, Centre for Research and Analysis of Migration, London

Card D (2009) Immigration and inequality. Am Econ Rev 992:1-21

Card D, Dustmann C, Preston I (2009) Immigration, wages, and compositional amenities. NBER working paper No. 15521, National Bureau of Economic Research, Cambridge

Carrasco R, Jimeno JF, Ortega AC (2008) The effect of immigration on the labor market performance of native-born workers: some evidence for Spain. J Popul Econ 21:627-648

Carrington WJ, de Lima PJF (1996) The impact of 1970s repatriates from Africa on the Portuguese labor market. Ind Labor Relat Rev 49:330-347

Chappell L, Lattore M, Rutter J, Shah J (2009) Migration and rural economies: assessing and addressing risks. Institute for Public Policy Research, London

Chellaraj G, Maskus KE, Mattoo A (2008) The contribution of international graduate students to US innovation. Rev Int Econ 16:444-462

Chiswick BR, Le AT, Miller PW (2008) How immigrants fare across the earnings distribution in Australia and the United States. Ind Labor Relat Rev 61:353-373

Chun Y (2008) Modeling network autocorrelation within migration flows by eigenvector spatial filtering. J Geograph Syst 10(4):317-344

Cohen-Goldner S, Paserman D (2006) Mass migration to Israel and natives' employment transitions. Ind Labor Relat Rev 59:630-652

Commander S, Kangasniemi M, Winters LA (2003) The brain drain: curse or boon? IZA DP No. 809, IZA Institute for the Study of Labor, Bonn

Constant A, Shachmurove Y, Zimmermann KF (2007) What makes an entrepreneur and does it pay? Native men, Turks, and other migrants in Germany. Int Migr 45:71-100

Cooper H, Hedges LV (1994) The handbook of research synthesis. Russel Sage Foundation, New York

Cortes P (2008) The effect of low-skilled immigration on U.S. prices: evidence from CPI data. J Political Econ 116:381-422

Cutler DM, Glaeser EL, Vigdor JL (2008) Is the melting pot still hot? Explaining the resurgence of immigrant segregation. Rev Econ Stat 90:478-497

Davidson R, MacKinnon J (2004) Econometric theory and methods. Oxford University Press, New York de Graaff T, Nijkamp P (2009) Socio-economic impacts of ethnic clustering on Dutch neighbourhoods: in search of optimal segregation levels. Socioecon Plann Sci (forthcoming)

De New JP, Zimmermann KF (1994) Native wage impacts of foreign labor: a random effects panel analysis. J Popul Econ 7:177-192

Donaghy KP (2009) CGE modeling in space: a survey. In: Capello R, Nijkamp P (eds) Handbook of regional growth and development theories. Edward Elgar, Cheltenham, pp 389-422

Duncan NT (2008) Brain drains, brain gains, and migration policies. In: Poot J, Waldorf B, van Wissen L (eds) Migration and human capital. Edward Elgar, Cheltenham, pp 259-280

Dustmann C, Fabbri F, Preston I (2005) The impact of immigration on the British labour market. Econ J 115:F324-F341

Dustmann C, Glitz A, Frattine T (2008) The labour market impact of immigration. Oxford Rev Econ Policy 24:477-494

Elhorst JP (2003) Specification and estimation of spatial panel data models. Int Reg Sci Rev 26:244-268

Fischer MM, Getis A (eds) (2010) Handbook of applied spatial analysis-software tools, methods and applications. Springer, Berlin

Friedberg RM (2001) The impact of mass migration on the Israeli labor market. Q J Econ 116:1373-1408

Friedberg RM, Hunt J (1995) The impact of immigrants on host country wages, employment and growth. J Econ Perspect 9:23-44 
Gans J (2007) The economic impacts of immigration in Arizona. Udall Center for Studies in Public Policy, University of Arizona, Tucson

Gavosto A, Venturini A, Villosio C (1999) Do immigrants compete with natives? Labour 13(3):603-621

GCIM (2005) Migration in an international world. Global Commission on International Migration, Geneva

Gorter C, Nijkamp P, Poot J (eds) (1998) Crossing borders. Ashgate, Aldershot

Greenwood MJ, Hunt GL, Kohli U (1996) The short-run and long-run factor-market consequences of immigration to the United States. J Reg Scienc 36:43-66

Greenwood MJ, Hunt GL, Kohli U (1997) The factor-market consequences of unskilled immigration to the United States. Labour Econ 4:1-28

Gross DM (2002) Three million foreigners, three million unemployed? Immigration flows and the labour market in France. Appl Econ 34:1969-1983

Gross DM (2004) Impact of immigrant workers on a regional labour market. Appl Econ Lett 11:405-408

Grossman JB (1982) The substitutability of natives and immigrants in production. Rev Econ Stat 64:596603

Hanson GH (2008) The economic consequences of the international migration of labor. NBER working paper 14490, National Bureau of Economic Research

Hatton TJ, Tani M (2005) Immigration and inter-regional mobility in the UK, 1982-2000. Econ J 115:F342-F358

Hunt J (1992) The impact of the 1962 repatriates from Algeria on the French labor market. Ind Labor Relat Rev 45:556-572

Hunt J, Gauthier-Loiselle M (2008) How much does immigration boost innovation? NBER working paper 14312, National Bureau of Economic Research

Johannsson H, Weiler S (2004) Local labor market adjustment to immigration: the roles of participation and the short run. Growth Chang 35:61-76

King AG, Lowell BL, Bean FD (1986) The effects of Hispanic immigrants on the earnings of native Hispanic Americans. Soc Sci Q 67:673-689

Kloosterman R, Rath J (2003) Immigrant entrepreneurs: venturing abroad in the age of globalization. Berg/University of New York Press, Oxford/New York

Kugler A, Yuksel M (2008) Effects of low-skilled immigration on U.S. natives: evidence from Hurricane Mitch. NBER working paper 14293, National Bureau of Economic Research

Lach S (2007) Immigration and prices. J Polit Econ 115:548-587

Lewis E (2004) How did the Miami labor market absorb the Mariel immigrants? Philadelphia, Federal Reserve Bank of Philadelphia working paper no. 04-3

Longhi S, Nijkamp P, Poot J (2005a) The fallacy of "job robbing": a meta-analysis of estimates of the effect of immigration on employment. J Migr Refug Issues 1:131-152

Longhi S, Nijkamp P, Poot J (2005b) A meta-analytic assessment of the effect of immigration on wages. J Econ Survey 19:451-477

Longhi S, Nijkamp P, Poot J (2008) Meta-analysis of empirical evidence on the labour market impact of immigration. Rég et Dév 27:161-191

Macura M, MacDonald AL, Haug W (eds) (2005) The new demographic regime. United Nations, Geneva

Maddux WW, Galinsky AD (2009) Cultural borders and mental barriers: the relationship between living abroad and creativity. J Pers Soc Psychol 96:1047-1061

Maré DC, Stillman S (2009) The impact of immigration on the labour market outcomes of New Zealanders. Economic impacts of immigration working paper. Department of Labour, Wellington

Mayr K, Peri G (2008) The importance of brain return in the brain drain-brain gain debate. Working paper 166, center for comparative immigration studies, University of California, San Diego

Mazzolari F, Neumark D (2009) Beyond wages: the effects of immigration on the scale and composition of output. NBER working paper 14900, National Bureau of Economic Research

Meyer BD (1995) Natural and quasi-experiments in economics. J Bus Econ Stat 13:151-161

Nana G, Sanderson K, Hodgson R (2009) Economic impacts of immigration: scenarios using a computable general equilibrium model of the New Zealand economy. IMSED Research, Department of Labour, Wellington

Nathan M (2008) Your place or mine? The local economics of migration. Institute for Public Policy Research, London

OECD (2009) International migration and the economic crisis: understanding the links and shaping policy responses. OECD Working Party on Migration, Paris

Okkerse L (2008) How to measure labour market effects of immigration: a review. J Econ Surv 22:1-30 
Ottaviano GIP, Peri G (2006) The economic value of cultural diversity: evidence from US cities. J Econ Geogr 6:9-44

Ottaviano GIP, Peri G (2008) Immigration and national wages: clarifying the theory and the empirics. NBER working paper 14188, National Bureau of Economic Research

Park S, Hewings GJD (2009) Immigration, aging, and the regional economy. Cityscape 11:59-80

Partridge J, Furtan H (2008) Increasing Canada's international competitiveness: is there a link between skilled immigrants and innovation? Paper presented at the American Agricultural Economics Assoc Annual Meeting, Orlando, FL July 27-29

Partridge MD, Rickman DS (2008) Computable general equilibrium (CGE) modeling for regional economic development analysis. Reg Stud 1-18. doi:10.1080/00343400701654236 (iFirst)

Partridge MD, Rickman DS, Ali K (2008) Recent immigration and economic outcomes in rural America. Am J Agric Econ 90:1326-1333

Pekkala Kerr S, Kerr WR (2008) Economic impacts of immigration: a survey. Working paper 09-013, Harvard Business School

Peri G (2007) Immigrants' complementarities and native wages: evidence from California, NBER working paper no. 12956, National Bureau of Economic Research, Cambridge

Peri G (2008) Immigration accounting: U.S. states 1960-2006, CReAM discussion paper no 05/08, Centre for Research and Analysis of Migration, London

Peri G (2009) The effect of immigration on productivity: evidence from US States. NBER working paper no. 15507, National Bureau of Economic Research, Cambridge

Peri G, Sparber C (2009) Task specialization, immigration, and wages. Am Econ J Appl Econ 1:135-169

Pischke J-S, Velling J (1997) Employment effects of immigration to Germany: an analysis based on local labor markets. Rev Econ Stat 79:594-604

Poot J (2008) Demographic change and regional competitiveness: the effects of immigration and ageing. Int J Foresight Innov Policy 4:129-145

Poot J, Cochrane B (2005) Measuring the economic impact of immigration: a scoping paper. Population studies centre discussion paper no. 48, University of Waikato, Hamilton

Pope D, Withers G (1993) Do migrants rob jobs? Lessons of Australian history, 1861-1991. J Econ Hist 53:719-742

Rephann TJ, Holm E (2004) Economic-demographic effects of immigration: results from a dynamic spatial microsimulation model. Int Reg Sci Rev 27:379-410

Saiz A (2003) Room in the kitchen for the melting pot: immigration and rental prices. Rev Econ Stat $85: 502-521$

Saiz A (2007) Immigration and housing rents in American cities. J Urban Econ 61:345-371

Sarris AH, Zografakis S (1999) A computable general equilibrium assessment of the impact of illegal immigration in the Greek economy. J Popul Econ 12:155-182

Smith JP, Edmonston B (1997) The new Americans: economic, demographic and fiscal effects of immigration. National Academy Press, Washington, DC

Sterne JAC (2009) Meta-analysis in Stata: an updated collection from the Stata Journal. Stata Press, College Station

Strutt A, Poot J, Dubbeldam J (2008) International trade negotiations and the trans-border movement of people: a review of the literature. PSC discussion paper no. 68, Population Studies Centre, University of Waikato

van der Gaag N, van Wissen L (2001) Determinants of the subnational distribution of immigration. Tijdschr Econ Soc Geogr 92:27-41

Venturini A, Villosio C (2006) Labour market effects of immigration: an empirical analysis based on Italian data. Int Labour Rev 145:91-118

Winter-Ebmer R, Zimmermann KF (1999) East-West trade and migration: the Austro-German case. In: Faini R, De Melo J, Zimmermann KF (eds) Migration, the controversies and the evidence. Cambridge University Press, Cambridge, pp 296-327

Winter-Ebmer R, Zweimuller J (1996) Immigration and the earnings of young native workers. Oxf Econ Pap 48:473-491

Winter-Ebmer R, Zweimuller J (1999) Do immigrants displace young native workers: the Austrian experience. J Popul Econ 12:327-340

Zorlu A, Hartog J (2005) The effect of immigration on wages in three European countries. J Popul Econ 18:113-151 